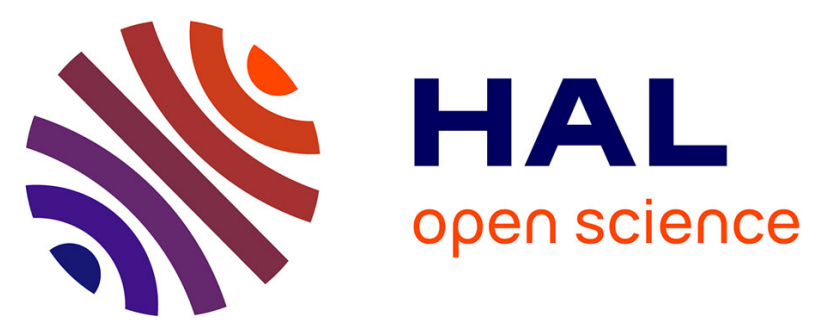

\title{
"Free" Volume Expansion and Formation Enthalpy of Defects as Key Parameters Tuning the Oxide Ionic Conductivity in Derivatives of $\beta$-La2Mo2O9
}

\author{
Gwenaël Corbel, Ania Selmi, Emmanuelle Suard, Philippe Lacorre
}

\section{To cite this version:}

Gwenaël Corbel, Ania Selmi, Emmanuelle Suard, Philippe Lacorre. "Free" Volume Expansion and Formation Enthalpy of Defects as Key Parameters Tuning the Oxide Ionic Conductivity in Derivatives of $\beta$-La2Mo2O9. Chemistry of Materials, 2014, 26 (23), pp.6838-6851. 10.1021/cm503461x . hal01952292

HAL Id: hal-01952292

https://hal-univ-lemans.archives-ouvertes.fr/hal-01952292

Submitted on 17 Jul 2019

HAL is a multi-disciplinary open access archive for the deposit and dissemination of scientific research documents, whether they are published or not. The documents may come from teaching and research institutions in France or abroad, or from public or private research centers.
L'archive ouverte pluridisciplinaire HAL, est destinée au dépôt et à la diffusion de documents scientifiques de niveau recherche, publiés ou non, émanant des établissements d'enseignement et de recherche français ou étrangers, des laboratoires publics ou privés. 


\title{
"Free" Volume Expansion and Formation Enthalpy of Defects as Key Parameters Tuning the Oxide Ionic Conductivity in Derivatives of $\beta-\mathrm{La}_{2} \mathrm{Mo}_{2} \mathrm{O}_{9}$
}

\author{
Gwenaël CORBEL ${ }^{1 *}$, Ania SELMI ${ }^{1}$, Emmanuelle SUARD $^{2}$ and Philippe LACORRE ${ }^{1}$ \\ ${ }^{1}$ LUNAM, Université du Maine, \\ Institut des Molécules et Matériaux du Mans, UMR-6283 CNRS, \\ Avenue Olivier Messiaen, 72085 Le Mans Cedex 9, France \\ ${ }^{2}$ Institut Laue-Langevin, BP 156, 38042 Grenoble Cedex 9, France
}

\begin{abstract}
The crystal structure of fast oxide-ion conductor $\beta$ $\mathrm{La}_{1.85} \mathrm{Ba}_{0.15} \mathrm{Mo}_{2} \mathrm{O}_{8.925}$ and its thermal evolution have been studied using neutron powder diffraction, and compared to those already published [G. Corbel et al., Chem. Mater. 2011, 23, 1288] of a bismuth counterpart in the LAMOX family, $\beta$ $\mathrm{La}_{1.7} \mathrm{Bi}_{0.3} \mathrm{Mo}_{2} \mathrm{O}_{9}$. Comparable evolutions have a tendency to suggest that the observed behavior, a specific combination of rotation and distortion of cationic building units, is a common feature of La-substituted $\beta$-LAMOX compounds. For the first time in crystallized solids, a quantitative link is made for both compounds between the high-temperature (high- $T$ ) conductivity increase relative to Arrhenius behavior and the volume expansion of the voids, through consecutive fits to crystallographic and conductivity data of the Dienes-Macedo-Litovitz (DML) equation. Both the expansion of the "free" volume $\left(V_{\mathrm{F}}\right)$ and the formation enthalpy of the Frenkel defects $\left(\Delta H_{\mathrm{f}}\right)$ are the key parameters tuning the conductivity of
\end{abstract}

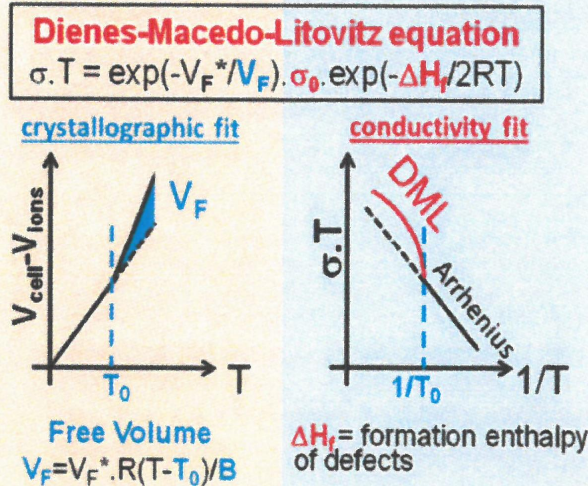

Dienes-Macedo-Litovitz equation $\sigma . T=\exp \left(-V_{F} N_{F}\right) \cdot \sigma_{0} \cdot \exp \left(-\Delta H_{1} / 2 R T\right)$

$V_{F}=V_{F}^{*} \cdot R\left(T-T_{0}\right) / B$ of defects LAMOX compounds above $T_{0}=400-450{ }^{\circ} \mathrm{C}$. A substitution strategy of $\mathrm{La}$ in $\mathrm{La}_{2} \mathrm{Mo}_{2} \mathrm{O}_{9}$ is proposed in order to optimize anionic conductivity, based on crystallographic grounds.

\section{INTRODUCTION}

Fast oxide ion conductors are of considerable interest for "clean" electrochemical applications, including solid oxide fuel cells, oxygen sensors, and oxygen separation membranes. In this field, Lacorre et al. discovered a novel oxide ion conductor 14 years ago: $\mathrm{La}_{2} \mathrm{Mo}_{2} \mathrm{O}_{9}{ }^{1,2}$ This binary oxide exhibits, above a first-order and reversible $\alpha$ (monoclinic, $P 2_{1}$ ) to $\beta$ (cubic, $P 2_{1} 3$ ) structural phase transition at $580^{\circ} \mathrm{C}$, an anionic conductivity $(5$ $\times 10^{-2} \mathrm{~S} \mathrm{~cm}^{-1}$ at $700{ }^{\circ} \mathrm{C}$ ) higher than that of the conventional $8 \mathrm{~mol} \%$ yttria-stabilized zirconia SOFC electrolyte ${ }^{3}$ (see Figure 1). Therefore, the strategy was to stabilize the high-temperature (high-T) anionically disordered cubic $\beta$-form through solidsolution formation in order to enhance the oxide ion conductivity at lower temperatures. Numerous possible substitutions such as $\left(\mathrm{La}_{2-x} \mathrm{~A}^{n+}{ }_{x}\right) \mathrm{Mo}_{2} \mathrm{O}_{9-(3-n) x / 2}\left(\mathrm{~A}^{+}=\mathrm{Na}^{4}\right.$ $\mathrm{K}_{,}{ }^{4-7} \mathrm{Rb}^{4} \mathrm{~A}^{2+}=\mathrm{Ca}, \mathrm{Sr}, \mathrm{Ba}, \mathrm{Pb}^{6-8} \mathrm{~A}^{3+}=\mathrm{Bi},{ }^{9} \mathrm{Pr},{ }^{10} \mathrm{Nd},{ }^{11,12}$ $\left.\mathrm{Eu},{ }^{13,14} \mathrm{Gd},{ }^{15} \mathrm{Y}^{15}\right), \quad \mathrm{La}_{2} \mathrm{Mo}_{2-y} \mathrm{~B}^{n+}{ }_{y} \mathrm{O}_{9-(6-n) y / 2} \quad\left(\mathrm{~B}^{5+}=\mathrm{V},{ }^{16}\right.$ $\left.\mathrm{Nb},{ }^{17,18} \mathrm{Ta}^{18} \mathrm{~B}^{6+}=\mathrm{S},{ }^{19} \mathrm{Cr},{ }^{20} \mathrm{~W}^{20,21}\right)$ and $\mathrm{La}_{2} \mathrm{Mo}_{2} \mathrm{O}_{(9-0.5 y)} \mathrm{F}_{y}{ }^{22}$ have been reported. Apart from $\mathrm{Na}^{+}, \mathrm{Pr}^{3+}, \mathrm{Nb}^{5+}$ and $\mathrm{F}^{-}$, most substitutes for $\mathrm{La}$ or $\mathrm{Mo}$ in $\mathrm{La}_{2} \mathrm{Mo}_{2} \mathrm{O}_{9}$ stabilize, above certain contents, the cubic $\beta$-form at room temperature.

These chemically $\beta$-stabilized LAMOX compounds exhibit, with a higher or lower magnitude, depending on the nature (isovalent/aliovalent with or without a lone pair) and the amount of substitute, a concomitant increase of the thermal expansion coefficient and of the conductivity above 400-450 ${ }^{\circ} \mathrm{C}$. ${ }^{13}$ Above $450{ }^{\circ} \mathrm{C}$, the thermal evolution of the conductivity can be satisfactorily fitted by a Vogel-Tammann-Fulcher (VTF) model, ${ }^{23-25}$ thus suggesting a regime of frameworkassisted mobility of oxide ions. A thorough temperaturecontrolled powder neutron diffraction study was carried out on a Bi-substituted LAMOX oxide ion conductor, $\beta$ $\mathrm{La}_{1.7} \mathrm{Bi}_{0.3} \mathrm{Mo}_{2} \mathrm{O}_{9}{ }^{26}$ in order to identify the subtle structural distortions at the origin of, or correlated to, the peculiarities of the ionic conduction process. This investigation revealed that the main distortions concern the geometry of the antitetrahedral $\left[\mathrm{O} 1(\mathrm{La}, \mathrm{Bi})_{3} \mathrm{Mo}\right]$ building units of the cationic framework hosting conducting anions, rather than the tilt/rotation of such units, as previously postulated. ${ }^{27}$ An analysis of the ionic displacements within these $\left[\mathrm{O} 1(\mathrm{La}, \mathrm{Bi})_{3} \mathrm{Mo}\right]$ units upon heating suggests that the successive expansions of $\left[(\mathrm{La}, \mathrm{Bi})_{3}\right]$ and $\left[(\mathrm{La}, \mathrm{Bi})_{2} \mathrm{Mo}\right]$ triangular faces enables some $\mathrm{O} 1$ oxide ions to escape from their initial position toward partially occupied $\mathrm{O} 2$ and $\mathrm{O} 3$ sites, respectively. The increase of ionic conductivity/ mobility observed above ca. $450{ }^{\circ} \mathrm{C}$ in $\beta-\mathrm{La}_{1.7} \mathrm{Bi}_{0.3} \mathrm{Mo}_{2} \mathrm{O}_{9}$ and ascribed to a transition toward a VTF-type assisted transport regime would consequently be due to the opening up of new conduction paths, rather than to an intrinsic increase in 


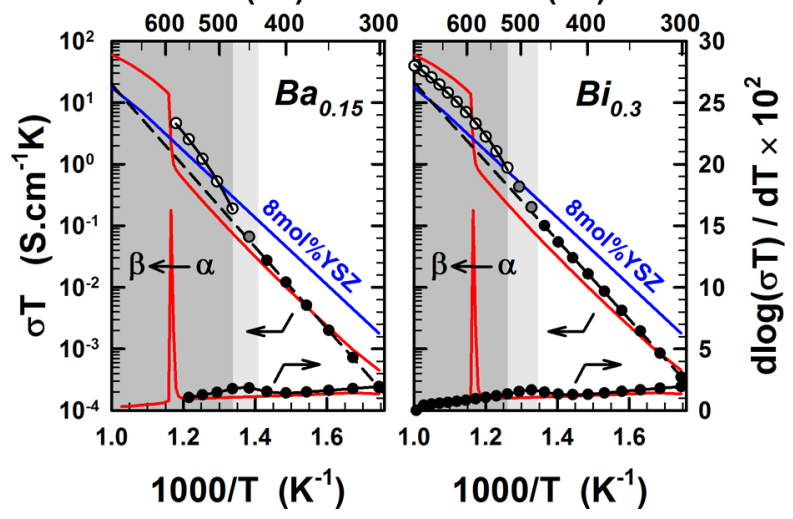

Figure 1. Temperature dependence of the electrical conductivity of $\beta$ $\mathrm{La}_{1.7} \mathrm{Bi}_{0.3} \mathrm{Mo}_{2} \mathrm{O}_{9}$ (black, gray, and open circles) and of $\beta$ $\mathrm{La}_{1.85} \mathrm{Ba}_{0.15} \mathrm{Mo}_{2} \mathrm{O}_{8.925}$ (black, gray, and open circles) compared to that of $\mathrm{La}_{2} \mathrm{Mo}_{2} \mathrm{O}_{9}$ (pellet sintered for $3 \mathrm{~h}$ at $1000{ }^{\circ} \mathrm{C}$, relative density $=$ 96(1)\% of theoretical density, solid red line) and to that of $8 \mathrm{~mol} \%$ yttria-stabilized zirconia (solid blue line, data taken from ref 3 ). The conductivity plot was fitted with a conventional Arrhenius law in the linear part at low temperature (dashed black line) and with the DML model when departure from linearity is observed at higher temperature (solid black line). Gray circles refer to a mixed Arrhenius-DML regime. At the bottom, a plot of the first derivative of the conduction, with respect to temperature, is shown (black circles).

mobility of $\mathrm{O} 2$ and $\mathrm{O} 3$ ions on their low-temperature conduction paths.

In 1959, Cohen and Turnbull ${ }^{28}$ proposed a microscopic interpretation of the VTF equation modeling the molecular transport in liquids:

$$
\phi T=A \exp \left[-\frac{B}{R\left(T-T_{0}\right)}\right]
$$

where $\phi$ is the fluidity. These authors postulated that a molecule vibrates about an equilibrium position until a redistribution of local "free" volumes opens up, in its vicinity, a void of sufficient size to jump into, thus facilitating its diffusion in the liquid. They showed that two parameters of this empirical VTF relation $\left(B\right.$ and $\left.T_{0}\right)$ are directly linked to the thermal expansion of the total "free" or empty volume available in the liquid for the diffusion of molecules. If a "free volume"type mechanism drives the oxide anion migration above 400$450{ }^{\circ} \mathrm{C}$ in the chemically $\beta$-stabilized LAMOX compounds, it implies that the distortions of the $\left[\mathrm{La}_{3} \mathrm{Mo}\right]$ antitetrahedra-based framework taking place above this temperature release a "free" volume. According to the Cohen and Turnbull interpretation, this "free" volume must expand as the distortions increase upon heating, to explain the singular increase of the conductivity observed. A rational fine-tuning of the "free" volume expansion is highly desirable to enhance the oxide ionic conductivity but is also challenging. Bearing in mind that the cationic framework of the $\beta-\mathrm{La}_{2} \mathrm{Mo}_{2} \mathrm{O}_{9}$ structure is composed of La corner-sharing $\left[\mathrm{O}_{\mathrm{La}} \mathrm{Mo}\right]$ antitetrahedra, increasing the average size of the bridging ion could open the way to increase the total "free" volume through the expansion in volume of both the antitetrahedron, the cages and the tunnels of the antistructure. Among all possible substitutes for lanthanum, only potassium (ionic radius in 10 -fold coordination of $1.59 \AA^{29}$ ), barium (ionic radius in 10 -fold coordination of $1.52 \AA^{29}$ ), or divalent lead (ionic radius in 10 -fold coordination of $1.40 \AA^{29}$ ) can increase, even at low substitution rate, the mean La site cation radius $\langle r\rangle$ more than $\mathrm{Bi}$ does in $\beta-\mathrm{La}_{1.7} \mathrm{Bi}_{0.3} \mathrm{Mo}_{2} \mathrm{O}_{9}(\langle r\rangle=1.276 \AA$ with an ionic radius for $\mathrm{La}^{3+}$ and $\mathrm{Bi}^{3+}$ in 10 -fold coordination of 1.27 and $1.31 \AA$, respectively ${ }^{29}$ ). Such partial substitutions of La by an element of lower valence change the oxide ion/vacancy balance. One can consider that both the increase of the mean La-site cation radius and the introduction of extrinsic oxygen vacancies could enhance the oxide ion migration. However, the reverse situation is observed in all aliovalently substituted LAMOX compounds reported in the literature. As shown by Marrero-López et al. ${ }^{6}$ or very recently by Takai et al., ${ }^{8}$ the ionic conductivity of $\mathrm{K}-, \mathrm{Ba}-$, and $\mathrm{Pb}$-substituted compounds remains lower than that measured at temperatures higher than $580{ }^{\circ} \mathrm{C}$ in the parent compound $\beta-\mathrm{La}_{2} \mathrm{Mo}_{2} \mathrm{O}_{9}$. Whatever the substitute considered, the conductivity decreases nonlinearly as the substitution rate increases.

Our previous investigations ${ }^{7}$ showed that the $\beta$-form of the highest $\mathrm{K}^{+}$- and $\mathrm{Ba}^{2+}$-substituted LAMOX exhibit an exsolution of $\beta$ - $\mathrm{KLaMo}_{2} \mathrm{O}_{8}$ and $\mathrm{BaMoO}_{4}$ scheelite-type phases above a temperature decreasing as the substitute content increases: $\mathrm{La}_{1.92} \mathrm{~K}_{0.08} \mathrm{Mo}_{2} \mathrm{O}_{8.92}\left(\sim 700{ }^{\circ} \mathrm{C}\right), \mathrm{La}_{1.88} \mathrm{~K}_{0.12} \mathrm{Mo}_{2} \mathrm{O}_{8.88}\left(\sim 500{ }^{\circ} \mathrm{C}\right)$, $\mathrm{La}_{1.85} \mathrm{Ba}_{0.15} \mathrm{Mo}_{2} \mathrm{O}_{8.925}\left(\sim 900-950{ }^{\circ} \mathrm{C}\right)$, and $\mathrm{La}_{1.8} \mathrm{Ba}_{0.2} \mathrm{Mo}_{2} \mathrm{O}_{8.9}$ $\left(\sim 700{ }^{\circ} \mathrm{C}\right)$. In this series, $\beta$ - $\mathrm{La}_{1.85} \mathrm{Ba}_{0.15} \mathrm{Mo}_{2} \mathrm{O}_{8.925}$ is the only composition combining both the "highest" mean La-site cation radius $(\langle r\rangle=1.289 \AA)$ and a stability of the $\beta$-form in a temperature range (up to $900{ }^{\circ} \mathrm{C}$ ) as large as the range explored in our previous structural analysis performed on $\beta$ $\mathrm{La}_{1.7} \mathrm{Bi}_{0.3} \mathrm{Mo}_{2} \mathrm{O}_{9}$ derivative, thus allowing a direct comparison. The objective of the current structural analysis on $\beta$ $\mathrm{La}_{1.85} \mathrm{Ba}_{0.15} \mathrm{Mo}_{2} \mathrm{O}_{8.925}$, undertaken by temperature-controlled neutron diffraction, was to understand why no enhancement of the ionic conductivity can be achieved through a concomitant increase of the mean La-site ionic radius and the introduction of extrinsic vacancies. In the first part of the paper, the temperature incidence on the geometry and tilts/rotations of $\left[\mathrm{O} 1 \mathrm{La}_{3} \mathrm{Mo}\right]$ elementary building units in $\beta$ $\mathrm{La}_{1.85} \mathrm{Ba}_{0.15} \mathrm{Mo}_{2} \mathrm{O}_{8.925}$ is at first carefully examined and then compared with the one previously determined in $\beta$ $\mathrm{La}_{1.7} \mathrm{Bi}_{0.3} \mathrm{Mo}_{2} \mathrm{O}_{9}$ to highlight the structural changes caused by barium. As shown in the current paper, the oxide ion conductivity of $\beta-\mathrm{La}_{1.85} \mathrm{Ba}_{0.15} \mathrm{Mo}_{2} \mathrm{O}_{8.925}$ and $\beta-\mathrm{La}_{1.7} \mathrm{Bi}_{0.3} \mathrm{Mo}_{2} \mathrm{O}_{9}$ at temperatures higher than $425{ }^{\circ} \mathrm{C}$ are similar, although the volume of the voids expands as the mean La-site ionic radius increases. This contradiction led us to reconsider the use of the VTF equation to describe the temperature dependence of the conductivity of LAMOX materials. Finally, we show how well the modification of the VTF equation proposed by Dienes, ${ }^{30}$ and Macedo and Litovitz, ${ }^{31}$ can relate the structural features of LAMOX materials to their transport property. A lanthanum substitution strategy based on crystallographic grounds is then proposed for enhancing the oxide ion conductivity of chemically $\beta$-stabilized $\mathrm{La}_{2} \mathrm{Mo}_{2} \mathrm{O}_{9}$ compounds above $400-450$ ${ }^{\circ} \mathrm{C}$.

\section{EXPERIMENTAL SECTION}

Synthesis. One gram of polycrystalline sample of $\beta$ $\mathrm{La}_{1.85} \mathrm{Ba}_{0.15} \mathrm{Mo}_{2} \mathrm{O}_{8.925}$ was prepared by conventional solid-state reaction from elementary oxides $\mathrm{La}_{2} \mathrm{O}_{3}$ (REacton, 99.9\%, from Alfa Aesar), $\mathrm{BaCO}_{3}$ (RP Normapur, 99.5\%, from Prolabo), and $\mathrm{MoO}_{3}$ (PURATREM $99.999 \%$ from Strem Chemicals). Prior to use, $\mathrm{BaCO}_{3}$ was kept dry in an air oven at $100{ }^{\circ} \mathrm{C}$ and $\mathrm{La}_{2} \mathrm{O}_{3}$ was calcined in air for $12 \mathrm{~h}$ at $1000{ }^{\circ} \mathrm{C}$ in order to remove adsorbed water and carbon dioxide $\left(\mathrm{CO}_{2}\right)$. Reactant powders were stoichiometrically weighed, thoroughly ground in an agate mortar, and initially heated in 
an alumina crucible at $500{ }^{\circ} \mathrm{C}$ for $12 \mathrm{~h}$. After several intermediate heatings and regrindings, a single $\beta$-phase was finally obtained after a final firing at $1000{ }^{\circ} \mathrm{C}$, followed by cooling to room temperature at a rate of $5{ }^{\circ} \mathrm{C} / \mathrm{min}$. Phase purity was checked by recording powder X-ray diffraction patterns at room temperature on a PANalytical $\theta / \theta$ BraggBrentano X'pert MPD PRO diffractometer ( $\mathrm{Cu} \mathrm{K} \alpha_{1+2}$ radiations) equipped with the X'Celerator multielement detector. The above process was performed 10 times to get the $10 \mathrm{~g}$ of $\beta$ $\mathrm{La}_{1.85} \mathrm{Ba}_{0.15} \mathrm{Mo}_{2} \mathrm{O}_{8.925}$ sample used in the neutron diffraction study.

Structural Characterization. A constant-wavelength (1.593641 $\AA$ ) neutron powder diffractogram was recorded in static air from the high-resolution two-axis diffractometer super-D2B of Institut Laue-Langevin (Grenoble, France) equipped with a standard ILL furnace. For data collection at and above room temperature, the 10-g sample of $\beta$-La ${ }_{1.85} \mathrm{Ba}_{0.15} \mathrm{Mo}_{2} \mathrm{O}_{8.925}$ was loaded in a cylindrical silica glass container open to air in order to avoid the molybdenum reduction upon heating. Temperature-controlled neutron diffractograms were collected at RT and then at $100{ }^{\circ} \mathrm{C}$ intervals between 100 and $900{ }^{\circ} \mathrm{C}$. Data were collected in the $\left[-7.45^{\circ}-162^{\circ}\right]$ scattering angle range for approximately $2 \mathrm{~h}$ at each temperature with a $0.05^{\circ}$ step. The program FullProf ${ }^{32}$ was used for Rietveld refinements. The lineshape was modeled by a standard pseudo-Voigt function using a Caglioti full width at half maximum (fwhm)-type function (refined parameters $U, V, W, \eta$ ) with a profile asymmetry correction (reported by Bérar and Baldinozzi ${ }^{33}$ ) below a scattering angle of $40^{\circ}$ in $2 \theta$ (two first adjustable parameters). In addition to the modulated background arising from short-range correlation of atomic positions $\mathrm{O} 2$ and $\mathrm{O} 3$ with fractional occupancies in $\beta-\mathrm{La}_{2} \mathrm{Mo}_{2} \mathrm{O}_{9}$-type structure, ${ }^{20,26,34,35}$ all neutron diffraction patterns collected in a cylindrical vitreous silica container in the temperature range from RT to $900{ }^{\circ} \mathrm{C}$ and shown in Figure 2 exhibit three parasitic broad peaks of the vitreous silica container at $Q$-wave vector positions of $1.5,2.9$, and $5.5 \AA^{-1}{ }^{36}$ Then, the wavy background intensity was estimated from linear interpolation between points manually selected in regions free from Bragg reflections of space group $P 2_{1} 3$ (No. 198). The Diamond software ${ }^{37}$ was used to draw the crystal structure.

Transport Property. A dense ceramic sample of $\beta$ $\mathrm{La}_{1.85} \mathrm{Ba}_{0.15} \mathrm{Mo}_{2} \mathrm{O}_{8.925}$ was obtained after cold pressing the ball-milled powder and sintering the pellet at $1000{ }^{\circ} \mathrm{C}$ (relative density $=94(2) \%$ of theoretical density), as extensively described in ref 13 . Thin Pt films electrodes were deposited by radio-frequency (RF) sputtering on both flat faces of the sintered pellet. Conductivity was measured by using a symmetric two-electrodes electrochemical cell connected to a Solartron 1296 dielectric interface and a Solartron 1260 frequency response analyzer. Complex impedance spectra were recorded over the $10 \mathrm{MHz}$ to $0.05 \mathrm{~Hz}$ range (AC signal amplitude of $50 \mathrm{mV}, 40$ points/ decade) under dry air flow every $25{ }^{\circ} \mathrm{C}$ (thermal equilibration for 35 $\mathrm{min})$ as the temperature increased from $300{ }^{\circ} \mathrm{C}$ to $575{ }^{\circ} \mathrm{C}$. As previously stated in $\beta$ - $\mathrm{La}_{1.9} \mathrm{Ba}_{0.1} \mathrm{Mo}_{2} \mathrm{O}_{8.95}{ }^{7}$ a decrease in conductivity resulting from the exsolution of $\mathrm{BaMoO}_{4}$ within the pellet takes place above $600-650{ }^{\circ} \mathrm{C}$, while the raw powder remains pure up to $900-$ $950{ }^{\circ} \mathrm{C}$. Thereby, no conductivity measurements on $\beta$ $\mathrm{La}_{1.85} \mathrm{Ba}_{0.15} \mathrm{Mo}_{2} \mathrm{O}_{8.925}$ were performed at temperatures higher than $575{ }^{\circ} \mathrm{C}$.

\section{RESULTS AND DISCUSSION}

Rietveld Refinements. The crystal structure of $\beta$ $\mathrm{La}_{1.85} \mathrm{Ba}_{0.15} \mathrm{Mo}_{2} \mathrm{O}_{8.925}$, at room temperature, has been refined from neutron powder diffraction pattern by the Rietveld method using the high-temperature cubic structure of $\beta$ $\mathrm{La}_{2} \mathrm{Mo}_{2} \mathrm{O}_{9}$ as a starting structural model. ${ }^{15}$ The site occupation factors for $\mathrm{La}$ and $\mathrm{Ba}$ in special positions (4a) were kept fixed to 0.925 and 0.075 , respectively, according to nominal Ba content. In our first structural model (model 1), it was postulated that the extrinsic oxygen vacancies introduced by the aliovalent substitution of lanthanum by barium were located on $\mathrm{O} 2 / \mathrm{O} 3$ sites, since no deficiency of the $\mathrm{O} 1$ site was earlier reported in $\beta-\mathrm{La}_{2} \mathrm{Mo}_{2} \mathrm{O}_{9}$ or $\beta-\mathrm{La}_{1.7} \mathrm{Bi}_{0.3} \mathrm{Mo}_{2} \mathrm{O}_{9}{ }^{26}$ Thereby, the occupancy of
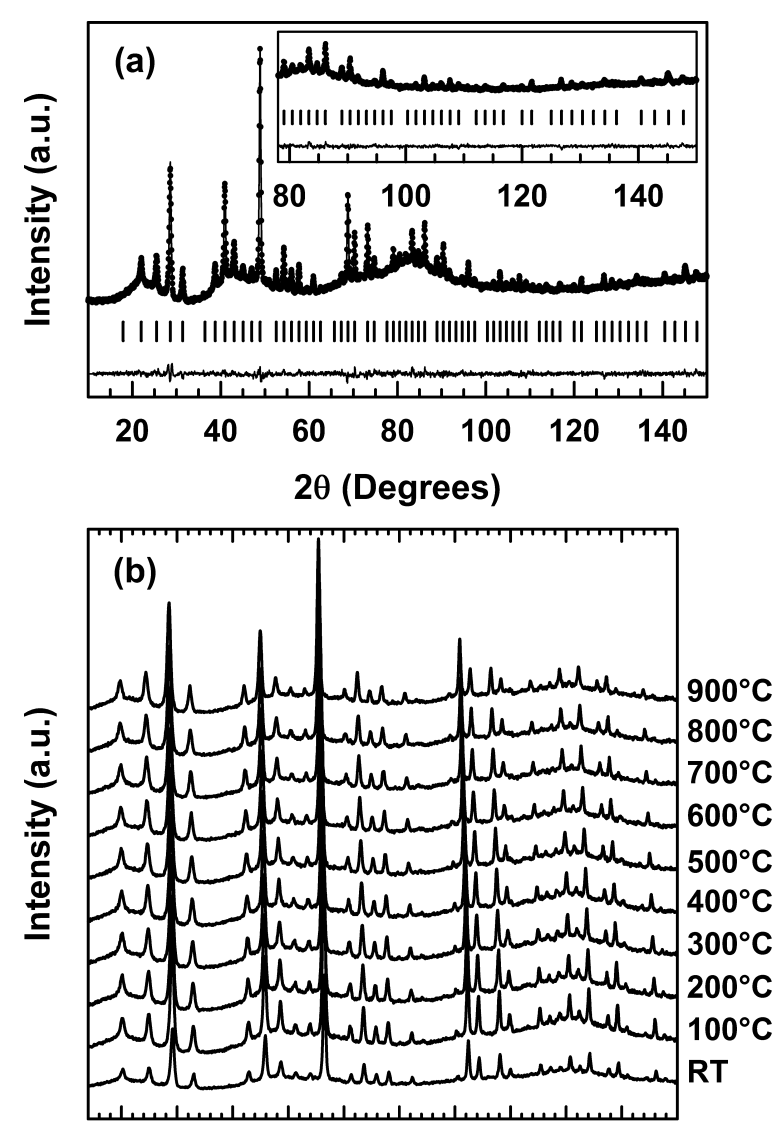

1.52 .02 .53 .03 .54 .04 .55 .05 .56 .06 .5

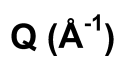

Figure 2. Neutron diffraction patterns of $\beta-\mathrm{La}_{1.85} \mathrm{Ba}_{0.15} \mathrm{Mo}_{2} \mathrm{O}_{8.925}$ : (a) observed (dots), calculated (lines), and difference (below) patterns at room temperature (RT) using the structural model in Table 1. Vertical markers give Bragg peak positions of space group $P 2{ }_{1} 3$ (No. 198). (b) Modulation of the background showing a first maximum around a $Q$ wave vector position of $2.75 \AA^{-1}(Q=4 \pi \sin \theta / \lambda)$ and the parasitic broad peaks of vitreous silica container at $1.5,2.9$, and $5.5 \AA^{-1}$ for patterns collected from RT to $900{ }^{\circ} \mathrm{C}$ (see text for details).

the $\mathrm{O} 3$ site was initially constrained with that of the $\mathrm{O} 2$ site to fulfill oxygen stoichiometry " $\mathrm{O}_{8.925}$ ". The anisotropic temperature factors $U_{i j}$ of $\mathrm{O} 3$ site were also constrained to those of O2. The neutron diffraction pattern collected at room temperature was satisfactorily modeled by least-squares fitting the structural model, which consisted of 10 atomic coordinates, 12 anisotropic thermal factors, $\mathrm{O} 2 / \mathrm{O} 3$ fractional site occupancies, and the cubic cell parameter $a$. Figure $2 \mathrm{a}$ shows the final observed, calculated, and difference diffraction patterns of $\beta-\mathrm{La}_{1.85} \mathrm{Ba}_{0.15} \mathrm{Mo}_{2} \mathrm{O}_{8.925}$ at room temperature. In Figure $2 \mathrm{~b}$, no trace of exsolved $\mathrm{BaMoO}_{4}$ is detected in the neutron diffraction patterns collected in the temperature range of 100$900{ }^{\circ} \mathrm{C}$. It confirms that raw powder of $\beta-\mathrm{La}_{1.85} \mathrm{Ba}_{0.15} \mathrm{Mo}_{2} \mathrm{O}_{8.925}$ is stable in air up to $900{ }^{\circ} \mathrm{C}$ and that the exsolution takes place at temperatures higher than $900{ }^{\circ} \mathrm{C}$. Then, successively, the structure refined at a lower temperature was used as starting model for refinement of the next-higher-temperature one. All neutron diffraction patterns were satisfactorily modeled by least-squares fitting this structural model. The values of atomic parameters (positions coordinates, equivalent isotropic temperature factors, ${ }^{38}$ and site occupancy factors) together with 


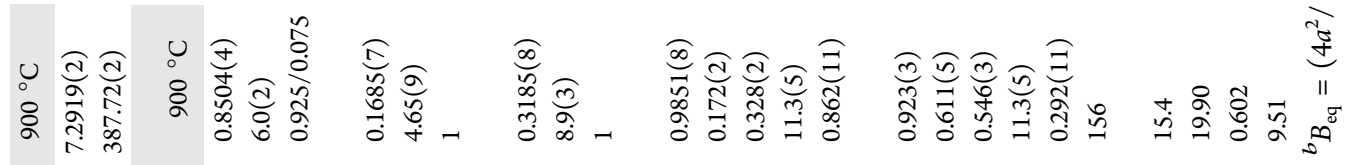

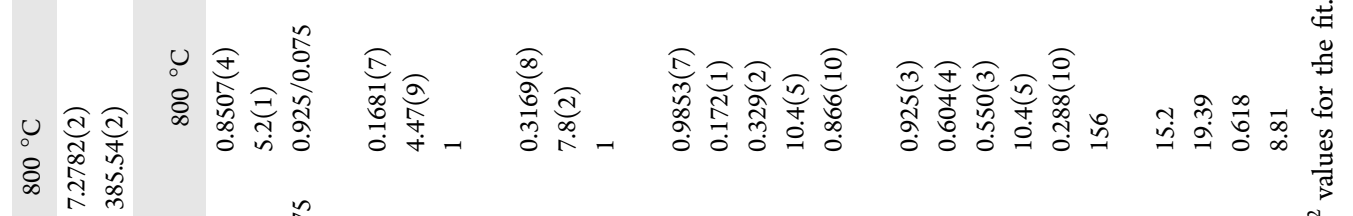

竞

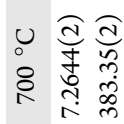

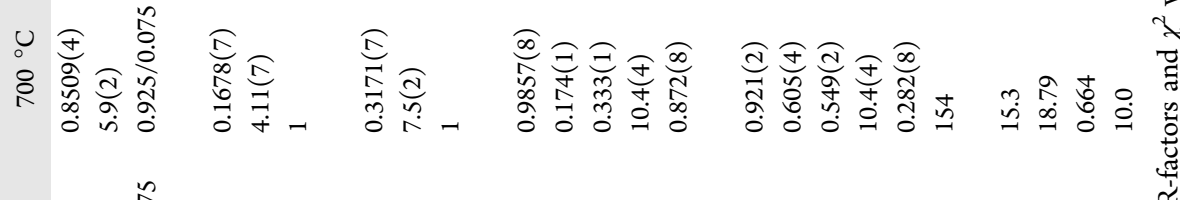

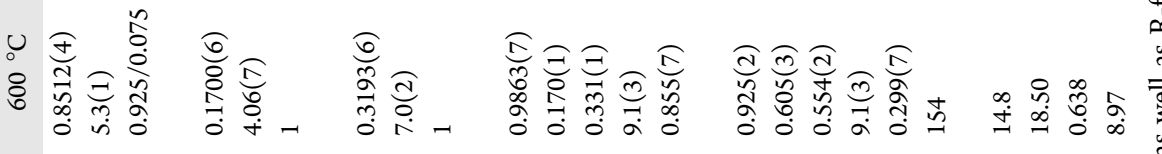

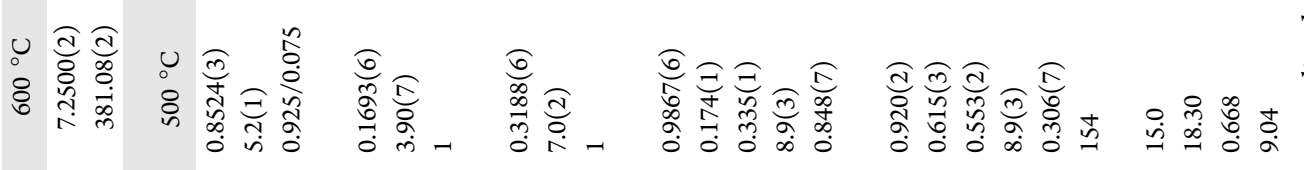

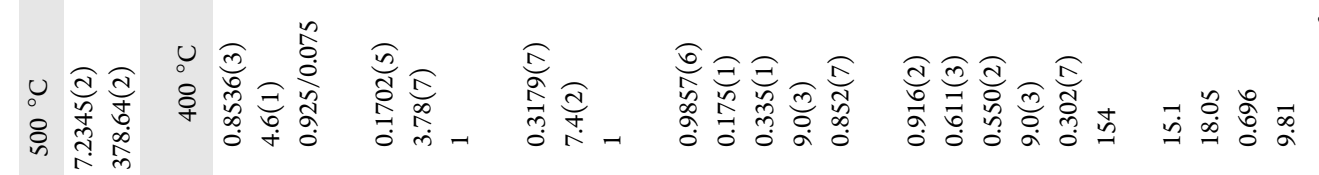

(a)

है

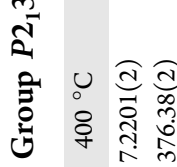

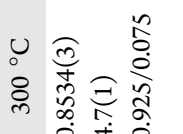

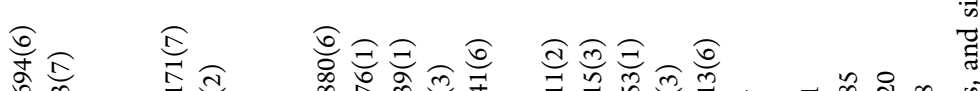

离

政

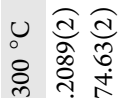

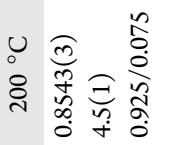

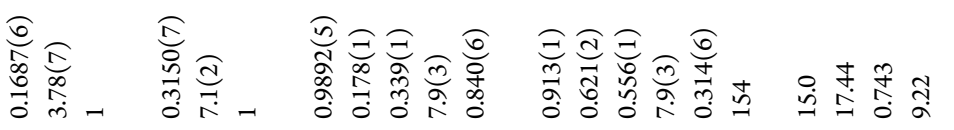

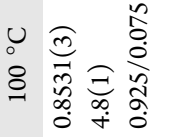

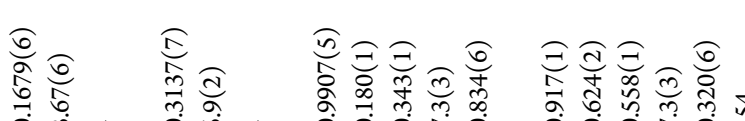

خ 
Table 2. Sintering Conditions, Relative Density, and Parameters of the Arrhenius and the Dienes-Macedo-Litovitz $(\mathrm{DML})^{30,31}$-Type Laws Determined for $\beta$ - $\mathrm{La}_{1.7} \mathrm{Bi}_{0.3} \mathrm{Mo}_{2} \mathrm{O}_{9}$ and $\beta$ - $\mathrm{La}_{1.85} \mathrm{Ba}_{0.15} \mathrm{Mo}_{2} \mathrm{O}_{8.925}$

\begin{tabular}{|c|c|c|}
\hline & $\beta-\mathrm{La}_{1.7} \mathrm{Bi}_{0.3} \mathrm{Mo}_{2} \mathrm{O}_{9}$ & $\beta-\mathrm{La}_{1.85} \mathrm{Ba}_{0.15} \mathrm{Mo}_{2} \mathrm{O}_{8.925}$ \\
\hline sintering conditions & $5 \mathrm{~h}, 875{ }^{\circ} \mathrm{C}$ & $12 \mathrm{~h}, 1000^{\circ} \mathrm{C}$ \\
\hline relative density (\%) & $98(1)$ & $94(2)$ \\
\hline \multicolumn{3}{|l|}{ Arrhenius regime, $\sigma T=\sigma_{0} \exp \left(-\frac{E_{\mathrm{a}}}{R T}\right)$} \\
\hline $\log \left(\sigma_{0}\right)\left(\mathrm{S} \mathrm{K} \mathrm{cm}{ }^{-1}\right)$ & 7.74 & 7.90 \\
\hline$E_{\mathrm{a}}(\mathrm{eV})$ & 1.27 & 1.31 \\
\hline$r^{2}$ & 0.9999 & 0.9999 \\
\hline \multicolumn{3}{|l|}{ DML regime, $\sigma T=\sigma_{0} \exp \left(-\frac{\Delta H_{f}}{2 R T}\right) \exp \left[-\frac{B}{R\left(T-T_{0}\right)}\right]$} \\
\hline $\log \left(\sigma_{0}\right)\left(\mathrm{S} \mathrm{K} \mathrm{cm}^{-1}\right)$ & 4.99 & 6.37 \\
\hline$\Delta H_{\mathrm{f}}(\mathrm{eV})$ & 1.10 & 1.68 \\
\hline$B(\mathrm{eV})$ & 0.037 & 0.028 \\
\hline$T_{0}\left({ }^{\circ} \mathrm{C}\right)$ & 402 & 376 \\
\hline$r^{2}$ & 0.999 & 0.999 \\
\hline migration enthalpy $\Delta H_{\mathrm{m}}{ }^{a}(\mathrm{eV})$ & 0.72 & 0.47 \\
\hline${ }^{a} E_{\mathrm{a}}=\Delta H_{\mathrm{f}} / 2+\Delta H_{\mathrm{m}}$ & & \\
\hline
\end{tabular}

conventional reliability factors, are reported in Table 1 for each temperature of the data collection.

At this stage, one can wonder whether the presence of extrinsic oxygen vacancies in the anionic sublattice of $\beta$ $\mathrm{La}_{1.85} \mathrm{Ba}_{0.15} \mathrm{Mo}_{2} \mathrm{O}_{8.925}$ could have changed the overall oxygen vacancy (intrinsic+extrinsic) distribution over the three crystallographic oxygen sites of the structure. Therefore, a second structural model (model 2) was tested, in which a slight $5 \%$ depletion of the $\mathrm{O} 1$ site to the benefit of $\mathrm{O} 2$ or $\mathrm{O} 3$ sites was introduced. The starting occupancy of each oxygen site was then calculated to fulfill oxygen stoichiometry " $\mathrm{O}_{8.925}$ ". The refinement of the occupancy factors of $\mathrm{O} 1, \mathrm{O} 2$, and $\mathrm{O} 3$ sites was performed while keeping all structural parameters fixed to values reported in Table 1 . To retain the " $\mathrm{O}_{8.925}$ " oxygen stoichiometry, occupancies of two oxygen sites were, in turn, constrained and refined. The deficiency of $\mathrm{O} 1$ site in $\beta$ $\mathrm{La}_{1.85} \mathrm{Ba}_{0.15} \mathrm{Mo}_{2} \mathrm{O}_{8.925}$ was $\sim 0.5(5) \%$ at $\mathrm{RT}$ or $900{ }^{\circ} \mathrm{C}$, thus remaining of the same order of magnitude as that the deficiency previously determined for $\beta$ - $\mathrm{La}_{1.7} \mathrm{Bi}_{0.3} \mathrm{Mo}_{2} \mathrm{O}_{9}(0.2(4) \%$ at 900 ${ }^{\circ} \mathrm{C}$ ). The absence of a significant depletion of $\mathrm{O} 1$ site implies that the (intrinsic+extrinsic) oxygen vacancies only reside at $\mathrm{O} 2$ and $\mathrm{O} 3$ sites whatever the temperature. The thorough structural analysis reported hereafter was thereby carried out from the crystallographic data of model 1 (Table 1).

Anionic Conductivity. The incidence of the aliovalent substitution of lanthanum by barium on the conductivity of $\mathrm{La}_{2} \mathrm{Mo}_{2} \mathrm{O}_{9}$ was earlier studied by Marrero-López et al. ${ }^{6}$ Their attention was focused on two compositions $x=0.025$ and 0.15 of the $\mathrm{La}_{2-x} \mathrm{Ba}_{x} \mathrm{Mo}_{2} \mathrm{O}_{9-x / 2}$ solid solution. The conductivity measurements were performed up to $950{ }^{\circ} \mathrm{C}$ on dense pellets directly prepared from nanocrystalline powders. Our temperature dependence of the bulk conductivity of $\beta$ $\mathrm{La}_{1.85} \mathrm{Ba}_{0.15} \mathrm{Mo}_{2} \mathrm{O}_{8.925}$ in the temperature range of $300-575$ ${ }^{\circ} \mathrm{C}$, displayed in Figure 1, is very similar to that found by these authors. However, none of their $x=0.025$ and $x=0.15$ compositions exhibit any decrease of conductivity at temperatures higher than $575{ }^{\circ} \mathrm{C}$. This discrepancy suggests that ballmilling of barium-substituted compounds is likely to involve an exsolution of $\mathrm{BaMoO}_{4}$ at a lower temperature than that reported for raw powders. As shown in Figure 1, the temperature dependence of the bulk conductivity of $\beta$ $\mathrm{La}_{1.85} \mathrm{Ba}_{0.15} \mathrm{Mo}_{2} \mathrm{O}_{8.925}$ composition in the temperature range of $300-425{ }^{\circ} \mathrm{C}$ can be satisfactorily fitted (correlation coefficient of $\left.r^{2}=0.9999\right)$ with a conventional Arrhenius-type law:

$$
\sigma T=\sigma_{0} \exp \left(-\frac{E_{a}}{R T}\right)
$$

Values of the pre-exponential factor $\left(\sigma_{0}\right)$ and the activation energy $\left(E_{\mathrm{a}}\right)$ are both reported in Table 2 . Note that our value of activation energy determined for the $x=0.15$ compound in the Arrhenius regime is identical to the value obtained by MarreroLópez et al. ${ }^{6}$ At temperatures higher than $425-450{ }^{\circ} \mathrm{C}$, the singular increase of the conductivity, characteristic of all chemically $\beta$-stabilized LAMOX compounds, is also observed for $\beta$ - $\mathrm{La}_{1.85} \mathrm{Ba}_{0.15} \mathrm{Mo}_{2} \mathrm{O}_{8.925}$. When compared to the conductivity of $\beta-\mathrm{La}_{1.7} \mathrm{Bi}_{0.3} \mathrm{Mo}_{2} \mathrm{O}_{9}$ above $425{ }^{\circ} \mathrm{C}$, no enhancement of the ionic conductivity is achieved through the concomitant increase of the mean La-site ionic radius and the introduction of extrinsic oxygen vacancies (see Figure 1).

Nonoccupied Cell Volume and Structural Distortion. As mentioned in the Introduction, by partially substituting trivalent lanthanum $\left(\mathrm{La}^{3+}\right)$ with larger divalent barium $\left(\mathrm{Ba}^{2+}\right)$, we expect to expand the voids of the cationic framework, in order to enhance the overall oxide ion mobility. Since the oxide ion conductivities of $\beta$ - $\mathrm{La}_{1.85} \mathrm{Ba}_{0.15} \mathrm{Mo}_{2} \mathrm{O}_{8.925}$ and $\beta-\mathrm{La}_{1.7} \mathrm{Bi}_{0.3} \mathrm{Mo}_{2} \mathrm{O}_{9}$ at temperatures higher than $425{ }^{\circ} \mathrm{C}$ are similar, what we want to know now is whether or not the volume of the voids in $\beta$ - $\mathrm{La}_{1.85} \mathrm{Ba}_{0.15} \mathrm{Mo}_{2} \mathrm{O}_{8.925}$ is higher than that in $\beta$ - $\mathrm{La}_{1.7} \mathrm{Bi}_{0.3} \mathrm{Mo}_{2} \mathrm{O}_{9}$.

Brown et al. have demonstrated that, in ionic solids, the magnitude of the bond lengthening when the temperature increases is dependent both on the amplitude of the thermal vibrations of atoms that form the bond and on the bond strength. ${ }^{39}$ Thus, the thermal volume expansion or contraction of the unit cell only originates from the lengthening of chemical bonds and the opening or closing of bond angles with increasing temperature, all ionic radii remaining constant. In $\beta$ $\mathrm{La}_{2} \mathrm{Mo}_{2} \mathrm{O}_{9}$, taking into account the partial occupancy of $\mathrm{O} 2$ and $\mathrm{O} 3$ sites, the average number of oxygen atoms surrounding $\mathrm{La}^{3+}$ and $\mathrm{Mo}^{6+}$ are 10 and 4.5, respectively. The values of the ionic 
radii for $\mathrm{La}^{3+}, \mathrm{Bi}^{3+}$, and $\mathrm{Ba}^{2+}$ in 10 -fold coordination tabulated by Shannon ${ }^{29}$ have been used to calculate the volume occupied by ions in the unit cell of $\beta$ - $\mathrm{La}_{1.7} \mathrm{Bi}_{0.3} \mathrm{Mo}_{2} \mathrm{O}_{9}$ and $\beta$ $\mathrm{La}_{1.85} \mathrm{Ba}_{0.15} \mathrm{Mo}_{2} \mathrm{O}_{8.925}$. With the coordination number of the Mo atom being half an integer, an ionic radius for $\mathrm{Mo}^{6+}$ of $r_{\mathrm{Mo}}$ $=0.455 \AA$ has been calculated, which is the average of ionic radii in four-fold ( $0.41 \AA)$ and five-fold ( $0.50 \AA)$ coordinations. At each temperature, the nonoccupied cell volume has been then calculated for both compounds by subtracting the volume occupied by ions from the cubic unit cell volume determined from Rietveld refinements of neutron diffraction patterns (see Table 1 and ref 26). Note that, a distinction must be made between the cell volume not occupied by ions and the "free" cell volume, which is considered to be the volume available for the migration of oxide ions. Figure 3 displays the evolution

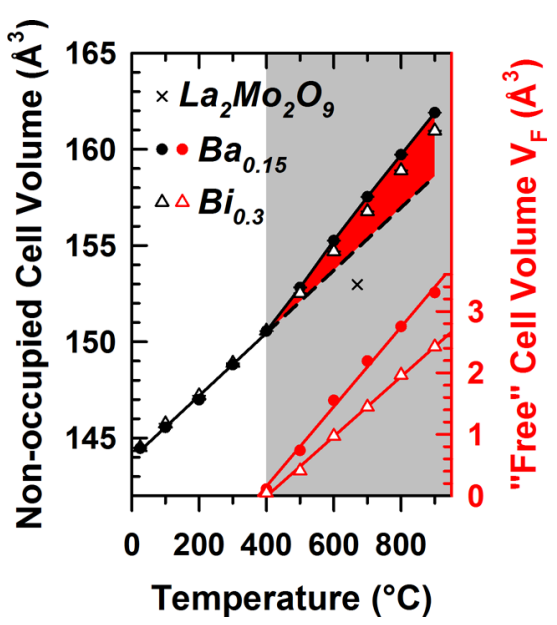

Figure 3. Comparison of temperature dependence of nonoccupied cell volume and of "free" volume for $\beta$ - $\mathrm{La}_{1.85} \mathrm{Ba}_{0.15} \mathrm{Mo}_{2} \mathrm{O}_{8.925}$ (circles, O) with that of $\beta$ - $\mathrm{La}_{1.7} \mathrm{Bi}_{0.3} \mathrm{Mo}_{2} \mathrm{O}_{9}$ (open triangles, $\triangle$ ), both determined from Rietveld refinement of temperature-controlled neutron diffraction data (see Table 1 and ref 26, respectively). Area shown in red corresponds to the "free" volume released by the distortive expansion of the cationic framework taking place above $400{ }^{\circ} \mathrm{C}$ in $\beta$ $\mathrm{La}_{1.85} \mathrm{Ba}_{0.15} \mathrm{Mo}_{2} \mathrm{O}_{8.925}$ (rotation and distortion of the antitetrahedron). The value of nonoccupied cell volume determined for $\beta-\mathrm{La}_{2} \mathrm{Mo}_{2} \mathrm{O}_{9}$ at $670{ }^{\circ} \mathrm{C}$ (cross symbol, $\times$ ) is added for reference (see details in the text).

against temperature of the nonoccupied cell volume for both compounds. It is worth mentioning that the spatial extension of the $\mathrm{Bi} 6 \mathrm{~s}^{2}$ lone pair in $\beta-\mathrm{La}_{1.7} \mathrm{Bi}_{0.3} \mathrm{Mo}_{2} \mathrm{O}_{9}$ (which roughly corresponds to the volume of an oxide anion ${ }^{40}$ ) was not considered into the calculation, since no significant distortion of the oxide coordination environment for $\mathrm{La} / \mathrm{Bi}$ cation site, characteristic of a high stereochemical activity of the lone pair, was noticed in our previous structural analysis. ${ }^{26}$

In Figure 3, two thermal domains with linear dependences of the nonoccupied cell volume are noticed below and above 400 ${ }^{\circ} \mathrm{C}$. The thermal volume expansion coefficient (TVEC, calculated from the slope and the intercept of the linear regression) increases from $11.3 \times 10^{-4}{ }^{\circ} \mathrm{C}^{-1}$ to $16.1 \times 10^{-4}$ ${ }^{\circ} \mathrm{C}^{-1}$ in the temperature range from $25-400{ }^{\circ} \mathrm{C}$ to $400-900$ ${ }^{\circ} \mathrm{C}$, respectively. It must be noted that the TVEC value at high temperature for $\beta$ - $\mathrm{La}_{1.85} \mathrm{Ba}_{0.15} \mathrm{Mo}_{2} \mathrm{O}_{8.925}$ is higher than the value determined in the same temperature range for $\beta$ $\mathrm{La}_{1.7} \mathrm{Bi}_{0.3} \mathrm{Mo}_{2} \mathrm{O}_{9}\left(11.2 \times 10^{-4}{ }^{\circ} \mathrm{C}^{-1}\right.$ and $14.7 \times 10^{-4}{ }^{\circ} \mathrm{C}^{-1}$ in the ranges of $25-400{ }^{\circ} \mathrm{C}$ and $400-900{ }^{\circ} \mathrm{C}$, respectively) whereas both compounds exhibit a similar expansion in nonoccupied cell volume at low temperature. In Figure 3, a difference in nonoccupied cell volume of $\sim 0.94 \AA^{3}(\sim 0.17 \%)$ is noted at $900{ }^{\circ} \mathrm{C}$ between the two derivatives of $\mathrm{La}_{2} \mathrm{Mo}_{2} \mathrm{O}_{9}$. Comparing the nonoccupied volume releases in the unit cell by the introduction of extrinsic vacancies (approximately $+1.58 \AA^{3}$ $=0.15 \times 4 / 3 \times \pi \times r_{\mathrm{V}}{ }^{3}$, where the ionic radius $\left(r_{\mathrm{V}}\right)$ of an oxygen vacancy corresponds to the ionic radius in triangular coordination $r_{\mathrm{O}}=1.36 \AA^{29}$ of the oxide ions $\mathrm{O}(2) / \mathrm{O}(3)$ in $\beta$ - $\left.\mathrm{La}_{2} \mathrm{Mo}_{2} \mathrm{O}_{9}{ }^{41}\right)$ with the increase of the volume occupied by cations in the unit cell $\left(\sim+1.34 \AA^{3}\right)$ due to the change in the nature and the amount of substitute $\left(\mathrm{La}_{1.7} \mathrm{Bi}_{0.3} \rightarrow \mathrm{La}_{1.85} \mathrm{Ba}_{0.15}\right)$, the gain in nonoccupied volume represents only one-fourth $\left(\sim 0.24 \AA^{3}\right)$ of the difference in the entire nonoccupied cell volume $\left(\sim 0.94 \AA^{3}\right)$ noted at $900{ }^{\circ} \mathrm{C}$ between $\mathrm{Bi}$ - and $\mathrm{Ba}$ substituted LAMOX compounds. In other words, the main increase in nonoccupied cell volume of $\sim+0.7 \AA^{3}$ at $900{ }^{\circ} \mathrm{C}$ (which also corresponds to the increase in unit-cell volume) originates from the structural distortion caused by the introduction of barium in the cationic framework. In order to determine these structural changes, the temperature incidence on the structural distortion of the $[\mathrm{O} 1(\mathrm{La} / \mathrm{Ba}) \mathrm{Mo}]$ host framework in $\beta$ - $\mathrm{La}_{1.85} \mathrm{Ba}_{0.15} \mathrm{Mo}_{2} \mathrm{O}_{8.925}$ has been carefully examined and compared with that reported for $\beta$ $\mathrm{La}_{1.7} \mathrm{Bi}_{0.3} \mathrm{Mo}_{2} \mathrm{O}_{9}$. The next section is devoted to such analysis.

Distortive Expansion of the [01(La/Ba)Mo] Host Framework upon Heating. In our previous thorough structural analysis carried out on $\beta$ - $\mathrm{La}_{1.7} \mathrm{Bi}_{0.3} \mathrm{Mo}_{2} \mathrm{O}_{9}$, the tunnels of the antistructure, hosting partially occupied $\mathrm{O} 2$ and $\mathrm{O} 3$ crystallographic sites, have been described as resulting from the $3 \mathrm{D}$ interconnections of small cages built up from seven $\mathrm{La} / \mathrm{Bi}$ corner-sharing $\left[\mathrm{O} 1(\mathrm{La} / \mathrm{Bi})_{3} \mathrm{Mo}\right]$ basic units. A complete description of the cage geometry has been proposed, using the following parameters:

- six intertetrahedral edge angles between adjacent La corner-sharing $\left[\mathrm{O}_{1 \mathrm{La}_{3} \mathrm{Mo}} \mathrm{M}\right.$ basic units: $\alpha=\mathrm{La} 1-\mathrm{La} 2-$ La3, $\beta=$ Mo-La1-La2, $\omega=\mathrm{La} 2-\mathrm{La} 3-\mathrm{La} 4, \gamma=\mathrm{La} 3-$ La4-La6, $\theta=$ La1-La5-La6 and $\phi=$ Mo-La5-La6,

- four cation-cation distances: La1-La3, La2-La4, and Mo-Mo represent the three "diagonals" of the cage, and Mo-La3 represents the "bottleneck" of tunnels.

Such a cage in $\beta-\mathrm{La}_{1.85} \mathrm{Ba}_{0.15} \mathrm{Mo}_{2} \mathrm{O}_{8.925}$ is isolated in Figure 4a. The evolutions of these intertetrahedral edge angles and cation-cation distances as a function of temperature have been determined from the data reported in Table 1 and are displayed in Figure $4 \mathrm{~b}$. To identify the change in cage geometry at the origin of the larger expansion in nonoccupied cell volume observed at high temperature for $\beta$ - $\mathrm{La}_{1.85} \mathrm{Ba}_{0.15} \mathrm{Mo}_{2} \mathrm{O}_{8.925}$, the temperature dependences of the above geometrical parameters were compared with those obtained for $\beta-\mathrm{La}_{1.7} \mathrm{Bi}_{0.3} \mathrm{Mo}_{2} \mathrm{O}_{9}$. As observed for the Bi-substituted $\mathrm{La}_{2} \mathrm{Mo}_{2} \mathrm{O}_{9}$, two different thermal behaviors of the tilt angle $|\delta|$ are noticed for $\beta$ $\mathrm{La}_{1.85} \mathrm{Ba}_{0.15} \mathrm{Mo}_{2} \mathrm{O}_{8.925}$. After a steady state in the temperature range from RT to $400{ }^{\circ} \mathrm{C}$, the tilt angle $|\delta|$ starts to increase before leveling off at temperatures higher than $600{ }^{\circ} \mathrm{C}$. Note that the leveling off in $\beta$ - $\mathrm{La}_{1.85} \mathrm{Ba}_{0.15} \mathrm{Mo}_{2} \mathrm{O}_{8.925}$ occurs at a temperature lower than that observed for $\beta-\mathrm{La}_{1.7} \mathrm{Bi}_{0.3} \mathrm{Mo}_{2} \mathrm{O}_{9}$ $\left(\sim 800^{\circ} \mathrm{C}\right)$, thus softening up the rise of antitetrahedra tilting in the Ba-substituted LAMOX over the temperature range of 400-900 ${ }^{\circ} \mathrm{C}$. In $\beta$ - $\mathrm{La}_{1.85} \mathrm{Ba}_{0.15} \mathrm{Mo}_{2} \mathrm{O}_{8.925}$, this increase of the tilt angle $|\delta|$ is, in regard to magnitude $\left(\Delta \mid \delta_{400-900}{ }^{\circ} \mathrm{C} \approx 0.8^{\circ}\right)$, almost two times smaller than that observed for $\beta$ - 
(a)

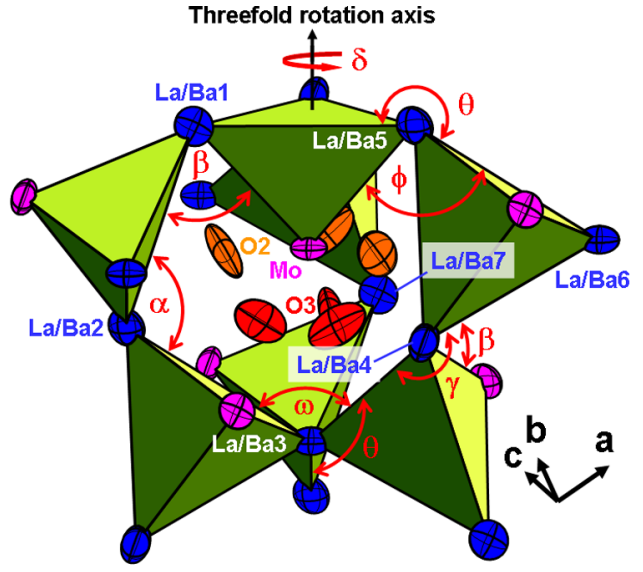

(b)
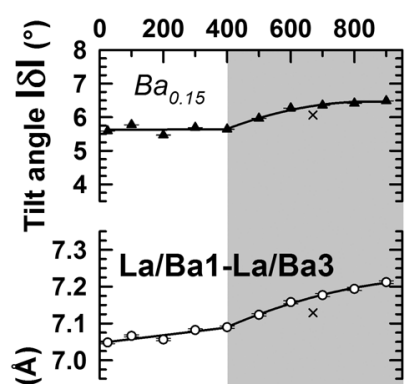

寻
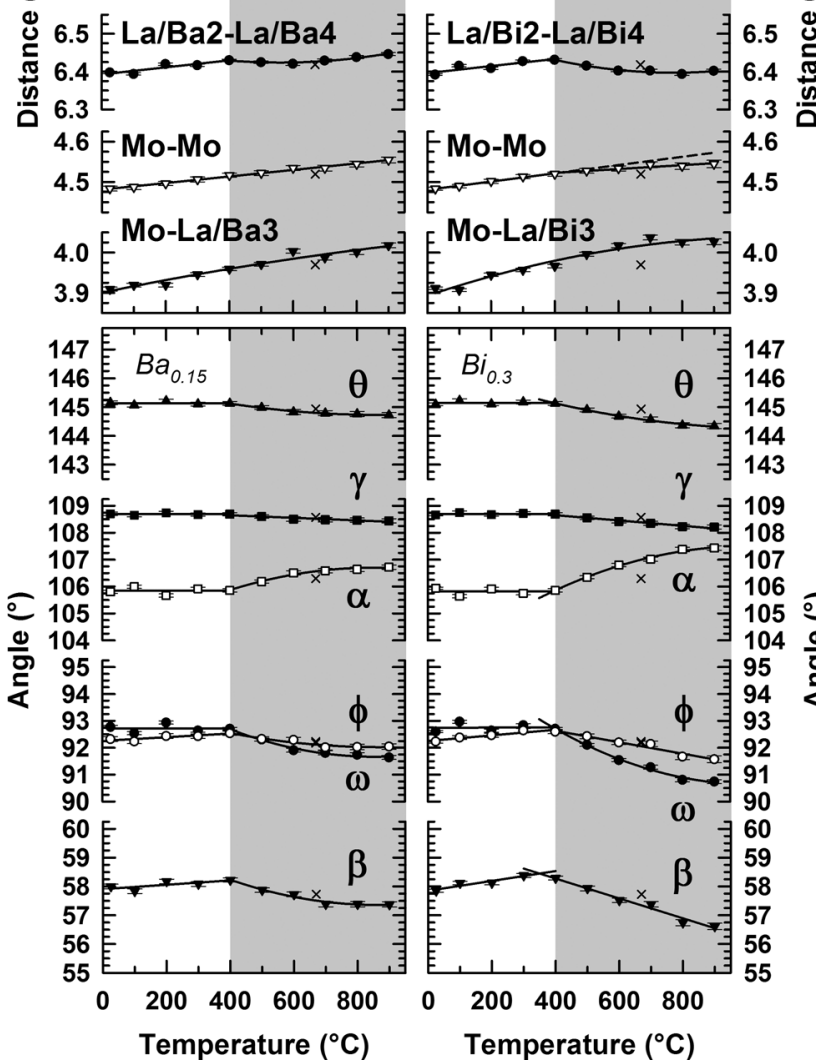

Figure 4. (a) Cage of the three-dimensional (3D) cationic framework, built up from seven $\mathrm{La} / \mathrm{Ba}$ corner-sharing $\left[\mathrm{O} 1(\mathrm{La} / \mathrm{Ba})_{3} \mathrm{Mo}\right]$ antitetrahedral basic units (green) hosting mobile $\mathrm{O} 2 / \mathrm{O} 3$ oxide ions in $\beta$ - $\mathrm{La}_{1.85} \mathrm{Ba}_{0.15} \mathrm{Mo}_{2} \mathrm{O}_{8.925}$. Thermal ellipsoids (at $50 \%$ probability) of $\mathrm{Mo}^{6+}$ (pink), $\mathrm{La}^{3+}$ or $\mathrm{Ba}^{2+}$ (blue), O2 (orange), and O3 (red) ion sites determined at room temperature from Rietveld refinement of neutron diffraction data (Table 1). (b) Comparison of temperature dependences of cation-cation distances and intertetrahedral edge angles
Figure 4. continued

within the cage for $\beta$-La ${ }_{1.85} \mathrm{Ba}_{0.15} \mathrm{Mo}_{2} \mathrm{O}_{8.925}$ (left) with that for $\beta$ $\mathrm{La}_{1.7} \mathrm{Bi}_{0.3} \mathrm{Mo}_{2} \mathrm{O}_{9}$ (right, ref 26). Variations are satisfactorily fitted with quadratic polynomial functions when departure from steady state or linear behavior is observed. The values determined for $\beta-\mathrm{La}_{2} \mathrm{Mo}_{2} \mathrm{O}_{9}$ at $670{ }^{\circ} \mathrm{C}$ (crosses) are added for reference (see details in the text).

$\mathrm{La}_{1.7} \mathrm{Bi}_{0.3} \mathrm{Mo}_{2} \mathrm{O}_{9}\left(\Delta \mid \delta_{400-900}{ }^{\circ} \mathrm{l} \approx 1.5^{\circ}\right)$. Nevertheless, Figure $4 \mathrm{~b}$ shows that edge angles and cation-cation distances within the cage of Ba-substituted LAMOX compound behave the same way as in $\beta-\mathrm{La}_{1.7} \mathrm{Bi}_{0.3} \mathrm{Mo}_{2} \mathrm{O}_{9}$ when the tilt angle $|\delta|$ increases in the range of $400-900{ }^{\circ} \mathrm{C}$. Even if the magnitude of the opening or closing of the intertetrahedral edge angles $\alpha\left(\Delta \alpha \approx+0.9^{\circ}\right), \gamma$ $\left(\Delta \gamma \approx-0.2^{\circ}\right), \theta\left(\Delta \theta \approx-0.4^{\circ}\right), \phi\left(\Delta \phi \approx-0.5^{\circ}\right), \beta(\Delta \beta \approx$ $\left.-0.8^{\circ}\right)$, and $\omega\left(\Delta \omega \approx-1.1^{\circ}\right)$ in $\beta-\mathrm{La}_{1.85} \mathrm{Ba}_{0.15} \mathrm{Mo}_{2} \mathrm{O}_{8.925}$ is nearly twice as small as that observed for $\beta-\mathrm{La}_{1.7} \mathrm{Bi}_{0.3} \mathrm{Mo}_{2} \mathrm{O}_{9}$ $\left(\Delta \alpha \approx+1.6^{\circ}, \Delta \gamma \approx-0.5^{\circ}, \Delta \theta \approx-0.8^{\circ}, \Delta \phi \approx-1^{\circ}, \Delta \beta \approx\right.$ $-1.3^{\circ}$, and $\left.\Delta \omega \approx-2^{\circ}\right)$, a closing down of framework's tunnels also occurs in the Ba-substituted LAMOX compound. Theses comparable evolutions tend to suggest that the observed thermal behavior is characteristic of La-substituted $\beta$-LAMOX compounds.

Let us now examine how the geometry of the $[\mathrm{O} 1(\mathrm{La} /$ $\mathrm{Ba})_{3} \mathrm{Mo}$ ] elementary building unit evolves with temperature. Figure 5 displays the thermal evolution of the $\mathrm{La} / \mathrm{Ba}-\mathrm{La} / \mathrm{Ba}$

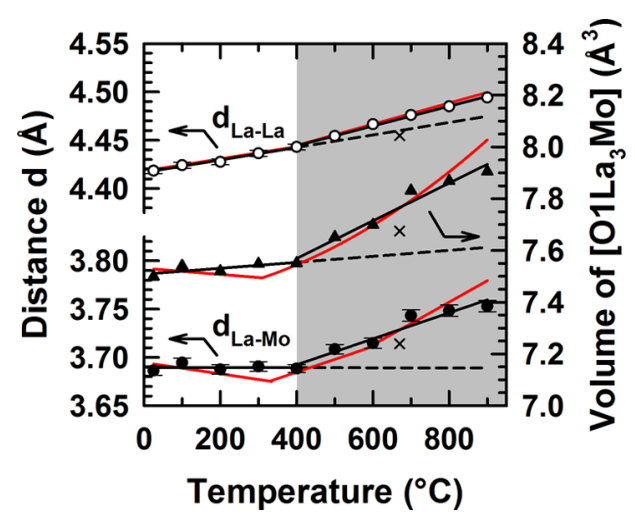

Figure 5. Comparison of thermal evolution of $\mathrm{La}-\mathrm{La}$ and $\mathrm{La}-\mathrm{Mo}$ edge lengths $(\AA)$ and of the volume $\left(\AA^{3}\right)$ of the $\left[\mathrm{O} 1 \mathrm{La}_{3} \mathrm{Mo}\right.$ ] antitetrahedral basic unit in $\mathrm{La}_{1.85} \mathrm{Ba}_{0.15} \mathrm{Mo}_{2} \mathrm{O}_{8.925}$ (open/black circles and black triangles) with that in $\beta-\mathrm{La}_{1.7} \mathrm{Bi}_{0.3} \mathrm{Mo}_{2} \mathrm{O}_{9}$ (solid red line, see ref 26). The values determined for $\beta-\mathrm{La}_{2} \mathrm{Mo}_{2} \mathrm{O}_{9}$ at $670{ }^{\circ} \mathrm{C}$ (cross symbols, $\times$ ) are added for reference (see details in the text).

and $\mathrm{La} / \mathrm{Ba}-\mathrm{Mo}$ distances within the $\left[\mathrm{O} 1(\mathrm{La} / \mathrm{Ba})_{3} \mathrm{Mo}\right]$ basic unit, determined from the experimental data reported in Table 1. Below and above $400{ }^{\circ} \mathrm{C}, \mathrm{La} / \mathrm{Ba}-\mathrm{La} / \mathrm{Ba}$ edges undergo two linear regimes of elongation (see Figure 5). The rates of lengthening $\left(\Delta d_{\mathrm{La} / \mathrm{Ba}-\mathrm{La} / \mathrm{Ba}} / \Delta T \approx 6.5 \times 10^{-5} \AA{ }^{\circ} \mathrm{C}^{-1}\right.$ and $\Delta d_{\mathrm{La} / \mathrm{Ba}-\mathrm{La} / \mathrm{Ba}} / \Delta T \approx 10.2 \times 10^{-5} \AA{ }^{\circ} \mathrm{C}^{-1}$ in the temperature ranges of $\mathrm{RT}-400{ }^{\circ} \mathrm{C}$ and $400-900{ }^{\circ} \mathrm{C}$, respectively) are comparable to those determined for $\mathrm{La} / \mathrm{Bi}-\mathrm{La} / \mathrm{Bi}$ edges in the Bi-substituted $\mathrm{La}_{2} \mathrm{Mo}_{2} \mathrm{O}_{9}$ sample $\left(\Delta d_{\mathrm{La} / \mathrm{Bi}-\mathrm{La} / \mathrm{Bi}} / \Delta T \approx 6.2 \times\right.$ $10^{-5} \AA^{\circ} \mathrm{C}^{-1}$ and $\Delta d_{\mathrm{La} / \mathrm{Bi}-\mathrm{La} / \mathrm{Bi}} / \Delta T \approx 10.8 \times 10^{-5} \AA^{\circ} \mathrm{C}^{-1}$ in the temperature ranges of $\mathrm{RT}-400{ }^{\circ} \mathrm{C}$ and $400-900{ }^{\circ} \mathrm{C}$, respectively). When the temperature increases from $\mathrm{RT}$ to $400{ }^{\circ} \mathrm{C}$ for $\beta-\mathrm{La}_{1.85} \mathrm{Ba}_{0.15} \mathrm{Mo}_{2} \mathrm{O}_{8.925}$, the La-Mo edges do not exhibit the slight contraction in length that is observed in $\mathrm{Bi}$ substituted $\mathrm{La}_{2} \mathrm{Mo}_{2} \mathrm{O}_{9}$, their lengths remaining constant up to $400{ }^{\circ} \mathrm{C}$. Above $400{ }^{\circ} \mathrm{C}$, an elongation of the $\mathrm{La} / \mathrm{Ba}-\mathrm{Mo}$ edges 
$\left(\Delta d_{\mathrm{La} / \mathrm{Ba}-\mathrm{Mo}} / \Delta T \approx 12.9 \times 10^{-5} \AA^{\circ} \mathrm{C}^{-1}\right)$ takes place, which is of lesser magnitude than the elongation of $\mathrm{La} / \mathrm{Bi}-\mathrm{Mo}$ edges determined in $\beta$ - $\mathrm{La}_{1.7} \mathrm{Bi}_{0.3} \mathrm{Mo}_{2} \mathrm{O}_{9}\left(\Delta d_{\mathrm{La} / \mathrm{Ba}-\mathrm{Mo}} / \Delta T \approx 18.6 \times\right.$ $\left.10^{-5} \AA^{\circ} \mathrm{C}^{-1}\right)$. It implies that the volume of the antitetrahedron in the barium derivative does not expand as much as that in $\beta$ $\mathrm{La}_{1.7} \mathrm{Bi}_{0.3} \mathrm{Mo}_{2} \mathrm{O}_{9}$ over the range of $400-900{ }^{\circ} \mathrm{C}$ (see Figure 5, reduction of the expansion by approximately $-0.11 \AA^{3}$ at 900 $\left.{ }^{\circ} \mathrm{C}\right)$. Thus, when the mean La-site cation radius slightly increases by $\Delta\langle r\rangle=+0.013 \AA$, the volume of the cationic framework, which is the cumulative volume of the four antitetrahedra contained in the unit cell, contracts by approximately $(-0.11 \times 4) \AA^{3}$ at $900{ }^{\circ} \mathrm{C}$.

Our previous thorough structural analysis, carried out on the Bi-substituted LAMOX, suggested that, above $400{ }^{\circ} \mathrm{C}$, the distortion/libration of the cationic tetrahedral $\left[(\mathrm{La} / \mathrm{Bi})_{3} \mathrm{Mo}\right]$ coordination of $\mathrm{O} 1$ oxide ion allows it to pass through the $\left[(\mathrm{La} / \mathrm{Bi})_{3}\right]$ and $\left[(\mathrm{La} / \mathrm{Bi})_{2} \mathrm{Mo}\right]$ triangular faces toward nearestneighboring vacancies at $\mathrm{O} 2$ or $\mathrm{O} 3$ sites. A structural evidence for the participation of site $\mathrm{O} 1$ to the oxide ion migration process above $400{ }^{\circ} \mathrm{C}$ in $\beta-\mathrm{La}_{1.7} \mathrm{Bi}_{0.3} \mathrm{Mo}_{2} \mathrm{O}_{9}$, was that $\mathrm{O} 1$ atom progressively moved away from the $\left[\mathrm{La}_{3}\right]$ base of the $[\mathrm{O} 1(\mathrm{La} /$ $\mathrm{Bi})_{3} \mathrm{Mo}$ antitetrahedron as the trigonal extension of this entity along the Mo apex increases in magnitude upon heating above this temperature (increase of the $\mathrm{O} 1-\mathrm{La} / \mathrm{Bi}$ and $\mathrm{O} 1-\mathrm{Mo}$ distances). As shown in Figure $S 1$ in the Supporting Information, and ref $26, \mathrm{O} 1-\mathrm{La} / \mathrm{Ba}$ and $\mathrm{O} 1-\mathrm{Mo}$ bond lengths in $\beta-\mathrm{La}_{1.85} \mathrm{Ba}_{0.15} \mathrm{Mo}_{2} \mathrm{O}_{8.925}$ behave, in the temperature range of $400-900{ }^{\circ} \mathrm{C}$, the same way as in $\beta-\mathrm{La}_{1.7} \mathrm{Bi}_{0.3} \mathrm{Mo}_{2} \mathrm{O}_{9}$. What we examine next is whether the increase of the mean La-site cation radius allows the $\mathrm{O} 1$ oxide ion to pass through the $\left[\mathrm{La}_{3}\right]$ and $\left[(\mathrm{La})_{2} \mathrm{Mo}\right]$ triangular faces more easily or less easily. The radius $r$ of the sphere tangent to the three atoms forming a triangular face of the antitetrahedron was calculated at each temperature for the two face types $\left[(\mathrm{La} / \mathrm{Ba})_{2} \mathrm{Mo}\right]$ and $\left[(\mathrm{La} / \mathrm{Ba})_{3}\right]$, according to the method detailed in ref 26 . The temperature dependences of $r$ for both $\left[(\mathrm{La} / \mathrm{Ba})_{2} \mathrm{Mo}\right]$ and $\left[(\mathrm{La} / \mathrm{Ba})_{3}\right]$ triangles and of the equivalent isotropic temperature factors for $\mathrm{La} / \mathrm{Ba}$ and Mo atoms are shown in Figure 6. In this figure, one can note that the two types of bottlenecks in $\beta$ $\mathrm{La}_{1.85} \mathrm{Ba}_{0.15} \mathrm{Mo}_{2} \mathrm{O}_{8.925}$ are slightly narrower than those existing in the $\mathrm{Bi}$ compound (difference in size varying from 0.01 to $0.02 \AA)$. Even if a reduction in the size of the bottlenecks was expected, because of the contraction in volume of the antitetrahedron, one can note that this reduction is, however, of the same order of magnitude as the increase of the mean Lasite cation radius $(\Delta\langle r\rangle=+0.013 \AA)$. When compared to the ionic radius $r_{\mathrm{O}}=1.36 \AA^{29}$ of an oxide ion in triangular coordination, the size of the two bottlenecks are too narrow in both compounds for an oxide ion to pass through the faces of the antitetrahedron, regardless of the temperature considered. In $\beta$ - $\mathrm{La}_{1.7} \mathrm{Bi}_{0.3} \mathrm{Mo}_{2} \mathrm{O}_{9}$, it has been shown that, above $400{ }^{\circ} \mathrm{C}$, the extra increase of thermal vibrations for $\mathrm{La} / \mathrm{Bi}$ and $\mathrm{Mo}$ atoms favors the distortion/opening of the bottlenecks, allowing the $\mathrm{O} 1$ ion migration. Comparing the strength of the $\mathrm{Ba}-\mathrm{O}$ bond $\left(562.0(13.4) \mathrm{kJ} / \mathrm{mol}^{42}\right)$ with that of the $\mathrm{Bi}-\mathrm{O}$ bond $\left(337.2(13.6) \mathrm{kJ} / \mathrm{mol}^{42}\right)$ and considering the large DebyeWaller thermal factor of oxygen atoms, one would expect that the vibration of the $\mathrm{Ba}$ atom would be of much higher magnitude than the vibration of the heavier Bi atom. In Figure 6 , surprisingly, the reverse situation is observed. At $900{ }^{\circ} \mathrm{C}$, a huge difference of $2 \AA^{2}$ is even noted between the atomic displacement parameters for $\mathrm{La} / \mathrm{Bi}$ and $\mathrm{La} / \mathrm{Ba}$ atoms. Over the range $400-900{ }^{\circ} \mathrm{C}$, the atomic displacement parameter for Mo
Temperature $\left({ }^{\circ} \mathrm{C}\right)$

Temperature $\left({ }^{\circ} \mathrm{C}\right)$
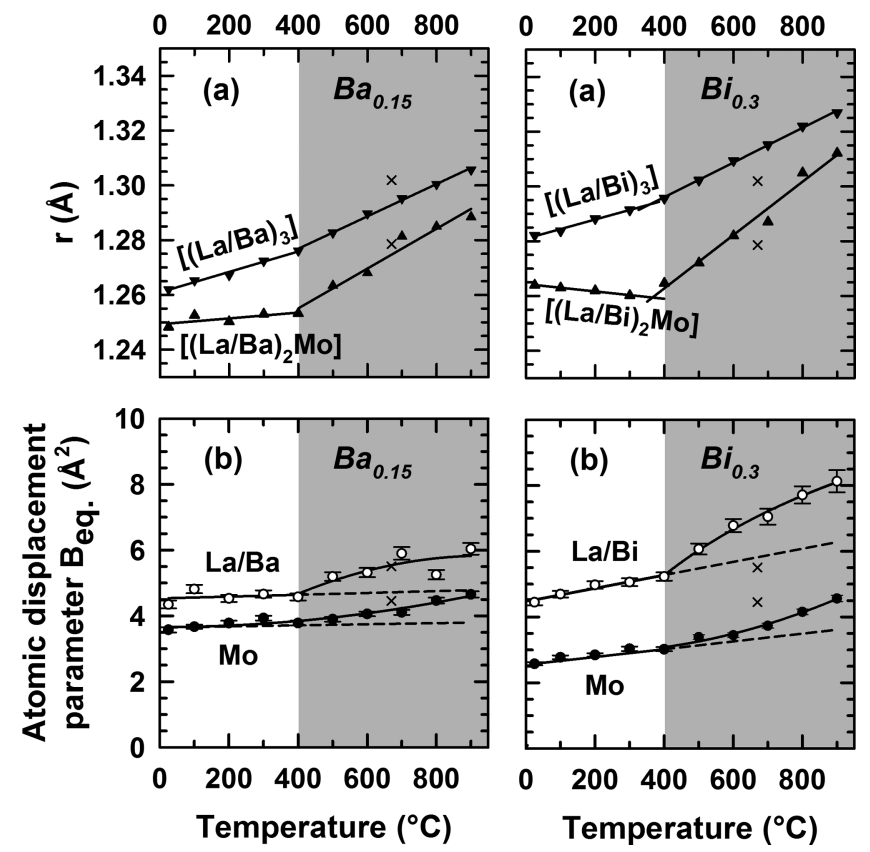

Figure 6. (a) Comparison of temperature dependences of the radius $r$ of the sphere tangent to the three atoms forming a triangular face of the $\left[\mathrm{O} 1 \mathrm{La}_{3} \mathrm{Mo}\right]$ antitetrahedron in $\beta$ - $\mathrm{La}_{1.85} \mathrm{Ba}_{0.15} \mathrm{Mo}_{2} \mathrm{O}_{8.925}$ (left) with that in $\beta-\mathrm{La}_{1.7} \mathrm{Bi}_{0.3} \mathrm{Mo}_{2} \mathrm{O}_{9}$ (right, ref 26). (b) Comparison of temperature dependences of equivalent isotropic temperature factors $B_{\text {eq }}$ for $\mathrm{La}$ and $\mathrm{Mo}$ atoms in $\beta$ - $\mathrm{La}_{1.85} \mathrm{Ba}_{0.15} \mathrm{Mo}_{2} \mathrm{O}_{8.925}$ (left) and $\beta$ $\mathrm{La}_{1.7} \mathrm{Bi}_{0.3} \mathrm{Mo}_{2} \mathrm{O}_{9}$ (right, ref 26). In panels (a) and (b), the values for $\beta$ $\mathrm{La}_{2} \mathrm{Mo}_{2} \mathrm{O}_{9}$ at $670{ }^{\circ} \mathrm{C}$ (cross symbols, $\times$ ) are added for reference (see details in the text).

atom in the Ba-substituted compound does not increase as much as that in $\beta-\mathrm{La}_{1.7} \mathrm{Bi}_{0.3} \mathrm{Mo}_{2} \mathrm{O}_{9}$, since it was already higher in the former than in the latter at temperatures below $400{ }^{\circ} \mathrm{C}$ (a difference of $\sim 1 \AA^{2}$ ). Despite this, both compounds have the same atomic displacement parameter for Mo atom at $900{ }^{\circ} \mathrm{C}$. From this consideration, the jumps of $\mathrm{O} 1$ oxygen ions toward the nearest-neighboring $\mathrm{O} 2$ and $\mathrm{O} 3$ sites in $\beta$ $\mathrm{La}_{1.85} \mathrm{Ba}_{0.15} \mathrm{Mo}_{2} \mathrm{O}_{8.925}$ seems to be less assisted by $\mathrm{La} / \mathrm{Ba}$ atoms than by $\mathrm{La} / \mathrm{Bi}$ atoms in the Bi-substituted compound. Nevertheless, the conductivity of both compounds remains similar above $450{ }^{\circ} \mathrm{C}$.

This contradiction incited us to closely look into the thermal evolution of the volumes of the cage and tunnels hosting mobile $\mathrm{O} 2$ and $\mathrm{O} 3$ ions in both compounds. The cage volume can be roughly estimated from the volume of the trigonal bipyramid centered on $\mathrm{O} 3$ sites and formed by Mo, La2, La3, La4, and La7 atoms, as shown in Figure 4a (calculation details are given in ref 26). The volume of tunnels is calculated by subtracting the volume of the framework from the volume of the cubic unit cell. The volume variations of the cage and of tunnels against temperature are displayed in Figure 7 for both $\beta-\mathrm{La}_{1.85} \mathrm{Ba}_{0.15} \mathrm{Mo}_{2} \mathrm{O}_{8.925}$ and $\beta-\mathrm{La}_{1.7} \mathrm{Bi}_{0.3} \mathrm{Mo}_{2} \mathrm{O}_{9}$ oxides. In the $\mathrm{Ba}-$ substituted compound, the volume of the cage undergoes two successive linear regimes of expansion below and above $400{ }^{\circ} \mathrm{C}$ (Figure 7a). Over the range of $\mathrm{RT}-400{ }^{\circ} \mathrm{C}$, the expansion of the cage in the Bi-substituted compound $\left(\sim 0.61 \AA^{3}\right)$ is slightly higher than in $\beta-\mathrm{La}_{1.85} \mathrm{Ba}_{0.15} \mathrm{Mo}_{2} \mathrm{O}_{8.925}\left(\sim 0.53 \AA^{3}\right)$. The difference mainly arises from the compression of the antitetrahedron along the $[\mathrm{O} 1-\mathrm{Mo}]$ direction taking place 


\section{Temperature $\left({ }^{\circ} \mathrm{C}\right)$}

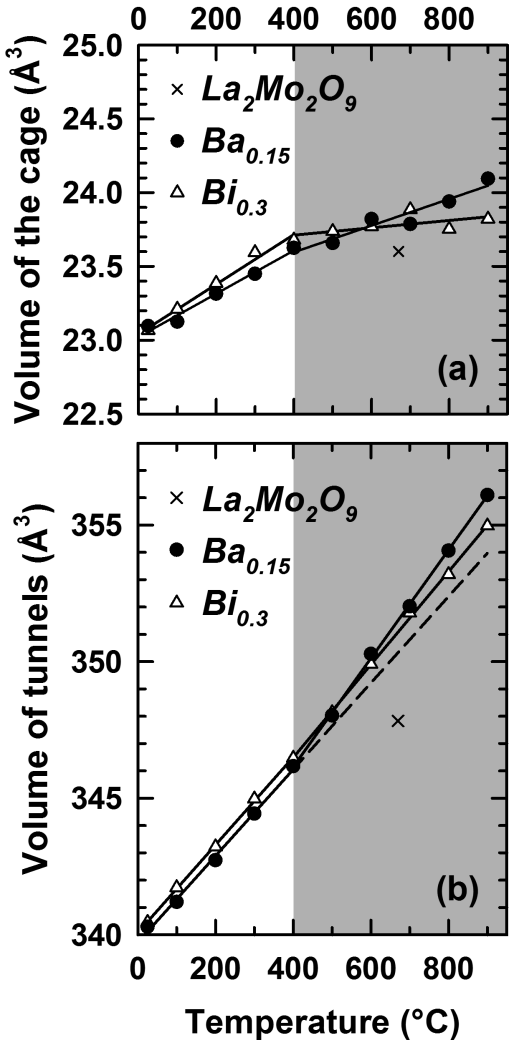

Figure 7. Volume variations of (a) the cage and (b) the tunnels of the $3 \mathrm{D}$ cationic framework, as a function of temperature in $\beta$ $\mathrm{La}_{1.85} \mathrm{Ba}_{0.15} \mathrm{Mo}_{2} \mathrm{O}_{8.925}$ (black circles, O) and in $\beta$ - $\mathrm{La}_{1.7} \mathrm{Bi}_{0.3} \mathrm{Mo}_{2} \mathrm{O}_{9}$ (open triangles, $\triangle$, ref 26). The values determined for $\beta-\mathrm{La}_{2} \mathrm{Mo}_{2} \mathrm{O}_{9}$ at $670{ }^{\circ} \mathrm{C}$ (cross symbols, $X$ ) are added for reference (see details in the text).

only in $\beta-\mathrm{La}_{1.7} \mathrm{Bi}_{0.3} \mathrm{Mo}_{2} \mathrm{O}_{9}$, which releases extra space in the cage. In the $\mathrm{Ba}$ derivative of $\mathrm{La}_{2} \mathrm{Mo}_{2} \mathrm{O}_{9}$, the expansion of the cage at temperatures lower than $400{ }^{\circ} \mathrm{C}$ is only due to the elongation of $\mathrm{La} / \mathrm{Ba} 1-\mathrm{La} / \mathrm{Ba} 3$ and $\mathrm{La} / \mathrm{Ba} 2-\mathrm{La} / \mathrm{Ba} 4$ distances as the temperature increases (see Figure $4 \mathrm{~b}$ ). Above $400{ }^{\circ} \mathrm{C}$, a slowing of the cage expansion is observed in $\beta$ $\mathrm{La}_{1.85} \mathrm{Ba}_{0.15} \mathrm{Mo}_{2} \mathrm{O}_{8.925}$, because of the trigonal extension of the antitetrahedron along the nonbridging Mo apex when it tilts in the cage. Over the range of $400-900{ }^{\circ} \mathrm{C}$, the higher extension and the twice-higher tilting in the cage of the antitetrahedron in $\beta-\mathrm{La}_{1.7} \mathrm{Bi}_{0.3} \mathrm{Mo}_{2} \mathrm{O}_{9}$ change the slowing of the cage expansion observed in $\beta$ - $\mathrm{La}_{1.85} \mathrm{Ba}_{0.15} \mathrm{Mo}_{2} \mathrm{O}_{8.925}$ into a leveling off in the former. Thereby, the volume expansion of the cage in $\beta$ $\mathrm{La}_{1.85} \mathrm{Ba}_{0.15} \mathrm{Mo}_{2} \mathrm{O}_{8.925}\left(\sim 0.47 \AA^{3}\right)$ over the range of $400-900{ }^{\circ} \mathrm{C}$ is three times higher than that reported in the Bi-substituted compound $\left(\sim 0.14 \AA^{3}\right)$. For all that, the cage in the Basubstituted compound exceeds in volume the cage in $\beta$ $\mathrm{La}_{1.7} \mathrm{Bi}_{0.3} \mathrm{Mo}_{2} \mathrm{O}_{9}$ above $600{ }^{\circ} \mathrm{C}$ only, with the difference in volume at $900{ }^{\circ} \mathrm{C}$ attaining a value of $\sim 0.27 \AA^{3}$. Note that this volume expansion of the cage at $900{ }^{\circ} \mathrm{C}$ does not correspond in magnitude to the volume contraction of the antitetrahedral framework reported at the same temperature $\left(\sim-0.44 \AA^{3}\right)$ when the mean La-site cation radius increases. The remaining volume released by this contraction $\left(\sim 0.17 \AA^{3}\right)$ is then inevitably distributed in the intercage space within the tunnels. In Figure $7 \mathrm{~b}$, one can however notice that the expansion of tunnels due to the contraction of the antitetrahedra $\left(\sim 0.44 \AA^{3}\right)$ represents only $38.9 \%$ of the entire volume expansion of tunnels $\left(\sim 1.13 \AA^{3}\right)$ reported at $900{ }^{\circ} \mathrm{C}$ when the mean La-site cation radius increases. It points out that most of the volume expansion of tunnels above $400{ }^{\circ} \mathrm{C}$ arises from a decrease of the antitetrahedra tilting caused by the increase in size of the ion bridging three entities. As a matter of fact, a difference in behavior is noticed when comparing the volume expansion of tunnels as a function of temperature in both compounds (see Figure $7 \mathrm{~b}$ ). Whereas the volume of tunnels in $\beta$ $\mathrm{La}_{1.7} \mathrm{Bi}_{0.3} \mathrm{Mo}_{2} \mathrm{O}_{9}$ continues to increase linearly above $400{ }^{\circ} \mathrm{C}$ with the same expansion rate that at low temperature, the tunnels in $\beta$ - $\mathrm{La}_{1.85} \mathrm{Ba}_{0.15} \mathrm{Mo}_{2} \mathrm{O}_{8.925}$ exhibit, above $400{ }^{\circ} \mathrm{C}$, an extra volume expansion, relative to its regular expansion observed at lower temperature. The release of extra empty space in the tunnels of the antistructure above $400{ }^{\circ} \mathrm{C}$ could make the migration of $\mathrm{O} 2$ and $\mathrm{O} 3$ ions within the tunnels easier in the barium derivative than in the bismuth one. Nevertheless, the conductivity of $\beta$ - $\mathrm{La}_{1.85} \mathrm{Ba}_{0.15} \mathrm{Mo}_{2} \mathrm{O}_{8.925}$ and $\beta$ $\mathrm{La}_{1.7} \mathrm{Bi}_{0.3} \mathrm{Mo}_{2} \mathrm{O}_{9}$ remains similar within the framework-assisted migration regime (see Figure 1 and the conductivity curve reported by Marrero-López et al. ${ }^{6}$ ). It suggests that, in the barium derivative of $\beta-\mathrm{La}_{2} \mathrm{Mo}_{2} \mathrm{O}_{9}$, either the easier migration of oxide ions in the tunnels balance the lower ability for $\mathrm{O} 1$ ion to escape its tetrahedral surrounding (and vice versa in the bismuth derivative) or this extra empty space is not available for migration. To be firmly conclusive about this point, attempts to determine the "free" volume and its role in the oxide ion conduction for both studied samples are presented in the next section.

On the Relative Role of "Free" Volume in the Oxide Ion Conduction. When a departure from linearity is observed at temperatures higher than $450{ }^{\circ} \mathrm{C}$ in $\beta$ $\mathrm{La}_{1.85} \mathrm{Ba}_{0.15} \mathrm{Mo}_{2} \mathrm{O}_{8.925}$ and $480{ }^{\circ} \mathrm{C}$ in $\beta$ - $\mathrm{La}_{1.7} \mathrm{Bi}_{0.3} \mathrm{Mo}_{2} \mathrm{O}_{9}$, the temperature dependence of the conductivity can be satisfactorily fitted with the empirical VTF model,

$$
\sigma T=\sigma_{0} \exp \left[-\frac{B}{R\left(T-T_{0}\right)}\right]
$$

as reflected in the high correlation coefficients $r^{2}$ obtained, respectively (see Figure S2 and Table S1 in the Supporting Information). The values of the pre-exponential factor $\left(\sigma_{0}\right)$, the pseudo-activation energy $(B)$, and the temperature $T_{0}$ are reported for both compounds in Table S1 in the Supporting Information. In their microscopic interpretation of the empirical VTF equation modeling, the molecular transport in a liquid (or temperature dependence of its fluidity) above the glass transition, Cohen and Turnbull ${ }^{28}$ assumed that a local "free" volume starts to appear around each molecule in the viscous liquid only above a critical temperature $T_{0}$. In their approach, a molecule is pictured as vibrating about an equilibrium position until a redistribution of local "free" volumes opens up, in its vicinity, a void of sufficient size into which it can jump. This redistribution would originate from the libration of the first nearest molecules surrounding the molecule in motion. If a "free volume"-type mechanism drives the oxide anion migration above $400-450{ }^{\circ} \mathrm{C}$ in chemically $\beta$ stabilized LAMOX compound, it implies that (i) a distribution of local "free" volumes exists only above $T_{0}$ within the [ $\mathrm{La}_{3} \mathrm{Mo}$ ] antitetrahedra-based framework hosting mobile oxide ions and (ii) the vibration/distortion of the cationic framework allows a redistribution of local "free" volumes as the oxide ion migrate, 
conductor, these defects are very likely anion Frenkel pairs $\mathrm{O}_{\mathrm{O}}^{\times}$ $\leftrightarrow \mathrm{O}_{\mathrm{i}}^{\prime \prime}+\mathrm{V}_{\mathrm{O}}^{\bullet \bullet}$ in the Kröger-Vink notation. ${ }^{43}$ When transposed to the ionic transport in a solid, the DML equation for the fluidity of a liquid becomes:

$$
\sigma T=\sigma_{0} \exp \left(-\frac{\Delta H_{\mathrm{f}}}{2 R T}\right) \exp \left[-\frac{B}{R\left(T-T_{0}\right)}\right]
$$

As pointed by Macedo and Litovitz, ${ }^{31}$ the data can be obviously fitted with four adjustable parameters $\left(\sigma_{0}, \Delta H_{\mathrm{f}}, B\right.$, and $\left.T_{0}\right)$ better than with three $\left(\sigma_{0}, B\right.$, and $\left.T_{0}\right)$. More recently, this equation was used to model the diffusion of alkaline ions in amorphous silicates above the glass-transition temperature $\left(T_{\mathrm{g}}\right)^{44}$

In order to restrict the number of parameters refined simultaneously when fitting the conductivity data of a given compound with the DML equation, the values of the pseudoactivation energy $B$ and the temperature $T_{0}$ were first determined from the linear regression analysis of the temperature dependence of $V_{\mathrm{F}} / V_{\mathrm{F}}^{*}$ obtained from neutron diffraction data. For each compound, the two remaining adjustable parameters of the model (pre-exponential factor $\sigma_{0}$ and the formation enthalpy of anion Frenkel pairs $\Delta H_{\mathrm{f}}$ ) were then refined in a second step when fitting the conductivity curve with the DML equation using the values of $B$ and $T_{0}$ parameters determined beforehand. The main advantage of the above procedure lies in the fact that the four parameters are determined through fits of experimental data and never empirically estimated or extrapolated for a part of them (as in ref 44 , for instance). It is also a way to possibly reconcile the analyses of neutron diffraction patterns and of complex impedance spectra. As demonstrated in Figure 1 and confirmed by the high value of the correlation coefficient $r^{2}$, the temperature dependence of the conductivity for both compounds can be satisfactorily fitted with a DML equation using the set of parameters displayed in Table 2. It is worth noting that the "free volume" term mostly determines the way the conductivity deviates above $400-450{ }^{\circ} \mathrm{C}$ from the linear Arrhenius regime at lower temperatures ("bending" term), while the magnitude of the conductivity change is controlled by the "enthalpic" term. From the values tabulated for $\beta$ $\mathrm{La}_{1.7} \mathrm{Bi}_{0.3} \mathrm{Mo}_{2} \mathrm{O}_{9}$ and $\beta$ - $\mathrm{La}_{1.85} \mathrm{Ba}_{0.15} \mathrm{Mo}_{2} \mathrm{O}_{8.925}$ compounds, the formation enthalpy of the Frenkel defects seems to play a significant role in determining the conductivity above $400-450$ ${ }^{\circ} \mathrm{C}$.

In $\beta$ - $\mathrm{La}_{1.7} \mathrm{Bi}_{0.3} \mathrm{Mo}_{2} \mathrm{O}_{9}$, the formation enthalpy of the Frenkel defects $\left(\Delta H_{\mathrm{f}}=1.1 \mathrm{eV}\right)$ is slightly higher than the value of 0.84 $\mathrm{eV}$ found in the literature ${ }^{45}$ for the $\mathrm{Ba}_{2} \mathrm{In}_{2} \mathrm{O}_{5}$, which is a brownmillerite oxide ion conductor that has intrinsic oxygen vacancies as $\mathrm{La}_{2} \mathrm{Mo}_{2} \mathrm{O}_{9}$. One can notice that this enthalpy $\left(\Delta H_{\mathrm{f}}\right)$ significantly increases when the mean La-site ionic radius increases in the $\beta$ - $\mathrm{La}_{2} \mathrm{Mo}_{2} \mathrm{O}_{9}$ structure. This explains why, despite a higher "free" volume expansion, the ionic conductivity of the $\beta-\mathrm{La}_{1.85} \mathrm{Ba}_{0.15} \mathrm{Mo}_{2} \mathrm{O}_{8.925}$ compound above $450{ }^{\circ} \mathrm{C}$ remains similar to that of the bismuth compound. A question immediately arises: Why is the formation enthalpy of the Frenkel defects $\left(\Delta H_{\mathrm{f}}\right)$ in $\beta$ - $\mathrm{La}_{1.85} \mathrm{Ba}_{0.15} \mathrm{Mo}_{2} \mathrm{O}_{8.925}$ so high? Atomistic simulation or density functional theory (DFT) calculations $^{46,47}$ and EXAFS/XANES ${ }^{48}$ measurements carried on yttria-stabilized zirconia reveal that the $\mathrm{Y}^{3+}$ cation, which is larger in size than the host $\mathrm{Zr}^{4+}$ cation, is preferentially located in the second-nearest-neighbor position with respect to the oxygen vacancy, thus implying that the vacancy is the first nearest neighbor to the host $\mathrm{Zr}^{4+}$ cation. This result is consistent with ${ }^{89} \mathrm{Y}$ NMR study of $8 \mathrm{~mol} \%$ yttria-stabilized zirconia, showing that $95 \%$ and $5 \%$ of $\mathrm{Y}$ ions are 8 -fold and 7 fold coordinated, respectively, to oxygen in the cubic fluoritetype structure. ${ }^{49}$ When the size of the substitute is very close to that of the host $\mathrm{Zr}^{4+}$ cation (the $\mathrm{Sc}^{3+}$ cation, for instance), a random vacancy distribution is achieved. It explains why $\mathrm{Sc}_{2} \mathrm{O}_{3}$ stabilized zirconia has the highest conductivity and the lowest activation energy of any known single aliovalently substituted zirconia. ${ }^{47,50}$ Taking into account the large size mismatch existing between $\mathrm{La}^{3+}$ and $\mathrm{Ba}^{2+}$ ions (difference in size of $0.25 \AA$ with ionic radius in 10 -fold coordination $\left.{ }^{29}\right)$, one can assume that the oxygen vacancies $\mathrm{V}_{\mathrm{O}}^{\bullet \bullet}$ in $\beta$ - $\mathrm{La}_{1.85} \mathrm{Ba}_{0.15} \mathrm{Mo}_{2} \mathrm{O}_{8.925}$ are preferentially located/formed in the surroundings of the La ion rather than that of the larger $\mathrm{Ba}^{2+}$ cation. When barium replaces lanthanum in the first-nearest-neighbor sphere of an oxide ion residing in a crystallographic site $\mathrm{O}_{\mathrm{O}}^{\times}$, it would become less energetically favorable for this oxide ion to jump into an interstitial site $\mathrm{O}_{\mathrm{i}}^{\prime \prime}$ and create an oxygen vacancy $\mathrm{V}_{\mathrm{O}}^{\bullet \bullet}$ in place of the original oxygen site. Thus, it gives a plausible explanation of the high enthalpy $\Delta H_{\mathrm{f}}$ determined for $\beta$-La $\mathrm{La}_{1.85} \mathrm{Ba}_{0.15} \mathrm{Mo}_{2} \mathrm{O}_{8.925}$. The fact that the $\beta-\mathrm{La}_{1.7} \mathrm{Bi}_{0.3} \mathrm{Mo}_{2} \mathrm{O}_{9}$ sample, for which the size mismatch between the host $\mathrm{La}^{3+}$ cation and the substitute (difference in size of $0.04 \AA$ for the $\mathrm{La}^{3+} / \mathrm{Bi}^{3+}$ pair with the ionic radius in 10 -fold coordination ${ }^{29}$ ) is the smallest, is also the composition having the lowest formation enthalpy of anion Frenkel $\mathrm{O}_{\mathrm{i}}^{\prime \prime}+\mathrm{V}_{\mathrm{O}}^{\bullet \bullet}$ pairs (see Table 2) strengthens this explanation. However, no certainty on a full random distribution of oxygen vacancies in $\beta$ - $\mathrm{La}_{1.7} \mathrm{Bi}_{0.3} \mathrm{Mo}_{2} \mathrm{O}_{9}$ can be claimed from this single criterion of size. Experimental evidence is needed to be firmly conclusive about this point. It is reasonable to think that the decrease of the conductivity observed in all cubic-substituted LAMOX compounds, chemically stabilized by $\mathrm{K}^{+}$or $\mathrm{Pb}^{2+}$ cations larger than $\mathrm{La}^{3+}$ in size, ${ }^{6,8}$ would also partially originate from the uneven distribution of oxygen vacancies in the structure.

\section{Identify a Substitution Strategy To Enhance the Oxide Ion Conduction of Chemically $\beta$-Stabilized LAMOX Compounds. Given what we observed for $\beta$ -} $\mathrm{La}_{1.85} \mathrm{Ba}_{0.15} \mathrm{Mo}_{2} \mathrm{O}_{8.925}$ and $\beta-\mathrm{La}_{1.7} \mathrm{Bi}_{0.3} \mathrm{Mo}_{2} \mathrm{O}_{9}$ samples, the substitution strategy of $\mathrm{La}$ to enhance the oxide ion conduction in chemically $\beta$-stabilized LAMOX compounds could be to optimize both the size match between lanthanum and the substituting element and the "free" volume expansion. If we consider the size match in $\beta-\mathrm{La}_{2} \mathrm{Mo}_{2} \mathrm{O}_{9}$ as ideal, what is the ideal "free" volume in this binary oxide? However, the "free" volume expansion resulting from the progressive rotation and distortion of the antitetrahedra in $\beta-\mathrm{La}_{2} \mathrm{Mo}_{2} \mathrm{O}_{9}$ cannot be determined, because of the first-order nature of its $\alpha / \beta$ structural phase transition at $580{ }^{\circ} \mathrm{C}$. Our attention was then focused on the nonoccupied cell volume, which is much easier to calculate. In addition, all structural parameters (tilting angle, volume of the antitetrahedron, size of the bottlenecks, etc.) analyzed in the present study were also determined for the parent compound $\mathrm{La}_{2} \mathrm{Mo}_{2} \mathrm{O}_{9}$ from neutron diffraction data collected at $670{ }^{\circ} \mathrm{C}$ (above its structural $\alpha / \beta$ phase transition). The crystal structure of $\beta-\mathrm{La}_{2} \mathrm{Mo}_{2} \mathrm{O}_{9}$ at $670{ }^{\circ} \mathrm{C}$ (see the CIF file in the Supporting Information) has been refined by the Rietveld method constraining the occupancy of the $\mathrm{O} 3$ site with that of the $\mathrm{O} 2$ site, as previously done for $\beta$ $\mathrm{La}_{1.85} \mathrm{Ba}_{0.15} \mathrm{Mo}_{2} \mathrm{O}_{8.925}$ and $\beta-\mathrm{La}_{1.7} \mathrm{Bi}_{0.3} \mathrm{Mo}_{2} \mathrm{O}_{9}$ compounds. Once the structural parameters for $\mathrm{La}_{2} \mathrm{Mo}_{2} \mathrm{O}_{9}$ were determined from these crystallographic data, they were compared with those 
obtained for the Ba- and Bi-substituted compounds (cross symbol $(X)$ in Figures 3-7).

First of all, the unit-cell volume of $\beta-\mathrm{La}_{2} \mathrm{Mo}_{2} \mathrm{O}_{9}(V=$ $\left.378.53(2) \AA^{3}\right)$ at $670{ }^{\circ} \mathrm{C}$ is determined to be smaller than the volumes calculated at this temperature for $\beta$ $\mathrm{La}_{1.85} \mathrm{Ba}_{0.15} \mathrm{Mo}_{2} \mathrm{O}_{8.925}\left(V=382.60 \AA^{3}\right)$ and $\beta-\mathrm{La}_{1.7} \mathrm{Bi}_{0.3} \mathrm{Mo}_{2} \mathrm{O}_{9}$ $\left(V=382.20 \AA^{3}\right)$ from a linear regression. But, most interestingly, the volume variation of the unit cell is 15 or 7 times higher in magnitude than the gain $\left(\sim 0.26 \AA^{3}\right)$ or the loss $\left(\sim-0.50 \AA^{3}\right)$ of nonoccupied volume solely caused by the partial $\mathrm{La} / \mathrm{Ba}$ or $\mathrm{La} / \mathrm{Bi}$ substitution, respectively. In terms of nonoccupied volume, its fraction for $\beta-\mathrm{La}_{2} \mathrm{Mo}_{2} \mathrm{O}_{9}$ at $670{ }^{\circ} \mathrm{C}$ $(\sim 40.4 \%)$ remains $0.4 \%-0.6 \%$ smaller than that calculated at this temperature for $\beta$ - $\mathrm{La}_{1.7} \mathrm{Bi}_{0.3} \mathrm{Mo}_{2} \mathrm{O}_{9}$ and $\beta$ $\mathrm{La}_{1.85} \mathrm{Ba}_{0.15} \mathrm{Mo}_{2} \mathrm{O}_{8.925}$ compounds, respectively (see Figure S4 in the Supporting Information). It is worth mentioning that the tilt angle $|\delta|$ (Figure 4), the volume of the antitetrahedron (Figure 5), and the volume of tunnels (Figure 7) in $\beta$ $\mathrm{La}_{2} \mathrm{Mo}_{2} \mathrm{O}_{9}$ at $670{ }^{\circ} \mathrm{C}$ are similar to the angle and volumes calculated for the substituted compounds at only $500{ }^{\circ} \mathrm{C}$. However, the conductivity of the two chemically $\beta$-stabilized LAMOX compounds at $500{ }^{\circ} \mathrm{C}\left(1000 / T \approx 1.29 \mathrm{~K}^{-1}\right.$ in Figure 1) remains much lower than the conductivity measured in the parent compound at $670{ }^{\circ} \mathrm{C}\left(1000 / T \approx 1.06 \mathrm{~K}^{-1}\right)$. It clearly suggests that increasing the fraction of nonoccupied volume (of total "free" volume) in the framework of $\beta-\mathrm{La}_{2} \mathrm{Mo}_{2} \mathrm{O}_{9}$ through relevant cationic substitution is not a way to enhance its oxide ion conduction. Thereby, the key parameter that determines, or has a strong impact on, the conductivity is the size match between lanthanum and the element substituting for it, rather than a high "free" volume expansion. For all of that, no matter how partial the role of the "free" volume expansion is in determining the conductivity, a minimum expansion is, however, required to ensure the assisted migration of oxide ions above $400-450{ }^{\circ} \mathrm{C}$. Keeping the fraction of nonoccupied volume (or of the "free" volume) above $600{ }^{\circ} \mathrm{C}$ in $\beta$-stabilized LAMOX as low as it is in $\beta$ - $\mathrm{La}_{2} \mathrm{Mo}_{2} \mathrm{O}_{9}$ could be a way to reach this minimum expansion of total "free" volume. An example to illustrate this point is the thermodynamically stable $\beta$ $\mathrm{La}_{1.75} \mathrm{Eu}_{0.25} \mathrm{Mo}_{2} \mathrm{O}_{9}$ phase. ${ }^{13}$ At $670{ }^{\circ} \mathrm{C}$, the pure and the Eusubstituted compounds have almost the same (minimum) fraction of the nonoccupied volume $(\sim 40.40 \%$ and $\sim 40.35 \%$, respectively, calculated from XRD data $\left.{ }^{13}\right)$. At $670^{\circ} \mathrm{C}$, the ionic conductivity of the $\beta-\mathrm{La}_{1.75} \mathrm{Eu}_{0.25} \mathrm{Mo}_{2} \mathrm{O}_{9}$ phase ${ }^{13}$ is lower than that measured for $\beta$ - $\mathrm{La}_{2} \mathrm{Mo}_{2} \mathrm{O}_{9}$. In this Eu-substituted LAMOX compound, a large size mismatch exists between lanthanum and the substitute (mean La site cation radius $\langle r\rangle$ from $1.27 \AA$ to $1.259 \AA$ with an ionic radius for $\mathrm{La}^{3+}$ and $\mathrm{Eu}^{3+}$ in 10 -fold coordination of 1.27 and $1.18 \AA$, respectively). Because of the very small difference in the fraction of the nonoccupied volume between $\beta$ - $\mathrm{La}_{1.75} \mathrm{Eu}_{0.25} \mathrm{Mo}_{2} \mathrm{O}_{9}$ and $\beta-\mathrm{La}_{2} \mathrm{Mo}_{2} \mathrm{O}_{9}$, the decrease of the conductivity observed when $\mathrm{La}^{3+}$ is partially substituted by $\mathrm{Eu}^{3+}$ can only be interpreted as originating from the uneven distribution of oxygen vacancies caused by the size mismatch between these two trivalent ions (trapping of oxygen vacancies around $\mathrm{Eu}^{3+}$ ions).

\section{CONCLUSION}

In this paper, the crystal structure of $\beta-\mathrm{La}_{1.85} \mathrm{Ba}_{0.15} \mathrm{Mo}_{2} \mathrm{O}_{8.925}$ was refined from neutron diffraction data at different temperatures in the range from room temperature (RT) to $900{ }^{\circ} \mathrm{C}$ in order to obtain deeper insight into the effect of barium on the transport properties. Whatever the temperature considered, the intrinsic oxygen vacancies, as well as extrinsic ones introduced by the aliovalent substitution of $\mathrm{La}^{3+}$ by $\mathrm{Ba}^{2+}$, only reside at the $\mathrm{O} 2$ and $\mathrm{O} 3$ crystallographic sites, as previously observed in $\beta$ - $\mathrm{La}_{1.7} \mathrm{Bi}_{0.3} \mathrm{Mo}_{2} \mathrm{O}_{9}$ or in the parent compound $\beta-\mathrm{La}_{2} \mathrm{Mo}_{2} \mathrm{O}_{9}$. The antistructure of the cubic $\mathrm{Ba}-$ substituted $\mathrm{La}_{2} \mathrm{Mo}_{2} \mathrm{O}_{9}$, built up from La corner-sharing $\left[\mathrm{O}_{\mathrm{La}} \mathrm{Mo}\right]$ antitetrahedra, is distorted upon heating the same way as in $\beta-\mathrm{La}_{1.7} \mathrm{Bi}_{0.3} \mathrm{Mo}_{2} \mathrm{O}_{9}$. It clearly shows that the complex distortive expansion, previously observed in $\beta$ $\mathrm{La}_{1.7} \mathrm{Bi}_{0.3} \mathrm{Mo}_{2} \mathrm{O}_{9}$, is probably representative of what happens in other La-substituted cubic members of the LAMOX family. When comparing the distortion of the antistructure of the two substituted compounds, the weak increase in the mean La-site cation radius, $\Delta\langle r\rangle=+0.013 \AA$ between $\beta$ - $\mathrm{La}_{1.7} \mathrm{Bi}_{0.3} \mathrm{Mo}_{2} \mathrm{O}_{9}$ and $\beta$ - $\mathrm{La}_{1.85} \mathrm{Ba}_{0.15} \mathrm{Mo}_{2} \mathrm{O}_{8.925}$, surprisingly induces a slight decrease in magnitude of the volume expansion of the $\left[\mathrm{O}_{1} \mathrm{La}_{3} \mathrm{Mo}\right.$ ] antitetrahedron taking place upon heating above 400-450 ${ }^{\circ} \mathrm{C}$. The resultant small reduction in the size of the triangular $\left[\mathrm{La}_{3}\right]$ and $\left[\mathrm{La}_{2} \mathrm{Mo}\right]$ bottlenecks through which the $\mathrm{O} 1$ oxide ion must pass, coupled with the large decrease in vibration amplitude of the La atom, suggest that its migration becomes less easy when the mean La-site ionic radius increases. Concomitantly, in the temperature range of $400-900{ }^{\circ} \mathrm{C}$, the increase in the average size of the ion bridging three $\left[\mathrm{O}_{1} \mathrm{La}_{3} \mathrm{Mo}\right]$ antitetrahedra restricts, in magnitude, the tilting of these entities in the cage and, thereby, the cage distortion. Contrary to what had been earlier observed in $\beta$ $\mathrm{La}_{1.7} \mathrm{Bi}_{0.3} \mathrm{Mo}_{2} \mathrm{O}_{9}$, the tunnels in $\beta-\mathrm{La}_{1.85} \mathrm{Ba}_{0.15} \mathrm{Mo}_{2} \mathrm{O}_{8.925}$ exhibit, above $400{ }^{\circ} \mathrm{C}$, an extra volume expansion relative to their regular expansion at lower temperature. The release of extra volume in the framework's tunnels results mainly from the weakening of the cage distortion and slightly from the smaller trigonal extension of the antitetrahedron along its nonbridging Mo apex pointing in the cage. This comparative structural study shows that the main structural change caused by barium in the structure concerns the tilt/rotation of the antitetrahedral building units of the cationic framework.

In all derivatives of $\beta-\mathrm{La}_{2} \mathrm{Mo}_{2} \mathrm{O}_{9}$, a singular increase of the conductivity is observed above $400-450{ }^{\circ} \mathrm{C}$, which can be satisfactorily fitted with the empirical Vogel-TammannFulcher (VTF) model, thus suggesting that the mechanism driving the oxide anion migration is of the "free volume" type. If so, the expansion/distortion of the host cationic framework above $400-450{ }^{\circ} \mathrm{C}$ should free up an empty volume favoring the migration of the oxide anion within it, according to the microscopic interpretation of the VTF equation proposed by Cohen and Turnbull. However, the anionic conductivities of $\beta$ $\mathrm{La}_{1.7} \mathrm{Bi}_{0.3} \mathrm{Mo}_{2} \mathrm{O}_{9}$ and $\beta$ - $\mathrm{La}_{1.85} \mathrm{Ba}_{0.15} \mathrm{Mo}_{2} \mathrm{O}_{8.925}$ remain similar above $400-450{ }^{\circ} \mathrm{C}$, despite a release of extra empty space in the tunnels hosting mobile $\mathrm{O} 2$ and $\mathrm{O} 3$ ions and the introduction of extrinsic oxygen vacancies in the latter. A deeper analysis of the temperature dependence of the anionic conductivity was performed by using two different models based on/derived from the "free" volume theory of the molecular transport in a liquid. Only the modification of the VTF equation proposed by Dienes, Macedo, and Litovitz allows, for the first time in a crystallized compound, to quantitatively link the singular increase of anionic conductivity above $400-450{ }^{\circ} \mathrm{C}$ to the volume expansion of the voids determined from neutron diffraction data. However, most interestingly, this thorough analysis has allowed us to identify the size match between lanthanum and the element substituting for it as a second key parameter that determines the anionic 
conductivity in chemically $\beta$-stabilized LAMOX compounds. When comparing $\beta-\mathrm{La}_{1.85} \mathrm{Ba}_{0.15} \mathrm{Mo}_{2} \mathrm{O}_{8.925}$ to the parent compound $\beta-\mathrm{La}_{2} \mathrm{Mo}_{2} \mathrm{O}_{9}$, it was shown, in this paper, that the size match has a much stronger impact on the conductivity than the "free" volume expansion. This study thus provides a plausible explanation for the conductivity decrease observed by several authors in cubic derivatives of $\beta-\mathrm{La}_{2} \mathrm{Mo}_{2} \mathrm{O}_{9}$ chemically stabilized by $\mathrm{K}^{+}, \mathrm{Ba}^{2+}$, or $\mathrm{Pb}^{2+}$ cations, which are larger in size than $\mathrm{La}^{3+}$. A substitution strategy to enhance the oxide ion conduction of $\beta$-stabilized LAMOX compounds, even to reach or exceed that of $\beta-\mathrm{La}_{2} \mathrm{Mo}_{2} \mathrm{O}_{9}$, would consist of (i) selecting the substitute the closest in size to that of lanthanum in order to promote a random oxygen vacancy distribution in the antistructure and (ii) adjusting the substitute amount to reach the minimum thermal expansion of total "free" volume required to ensure the assisted migration of the oxide ion. To fulfill the second condition, the fraction of nonoccupied volume above $600{ }^{\circ} \mathrm{C}$ in $\beta$-stabilized LAMOX must be kept as low as it is in $\beta-\mathrm{La}_{2} \mathrm{Mo}_{2} \mathrm{O}_{9}$. Only a determination of the cubic unit-cell volume of $\beta$-stabilized LAMOX compounds through Le Bail fit of the X-ray diffraction (XRD) pattern collected at high temperature is necessary to evaluate this fraction of nonoccupied volume, thus allowing the rapid screening of potential highly conducting compositions.

\section{ASSOCIATED CONTENT}

\section{Supporting Information}

(1) Thermal evolution of O1-cation bond lengths, of the distance between $\mathrm{O} 1$ and the $\left[(\mathrm{La} / \mathrm{Ba})_{3}\right]$ base and of bond angles within the $\left[\mathrm{O} 1(\mathrm{La} / \mathrm{Ba})_{3} \mathrm{Mo}\right]$ antitetrahedral basic unit, as a function of temperature in $\beta-\mathrm{La}_{1.85} \mathrm{Ba}_{0.15} \mathrm{Mo}_{2} \mathrm{O}_{8.925}$. (2) Dependence of the electrical conductivity at high temperature fitted with the Vogel-Tammann-Fulcher (VTF) model. (3) Comparison of the temperature dependences of the "free" cell volumes $\left(V_{\mathrm{F}}\right)$, deduced from the analysis of neutron diffraction patterns and of complex impedance spectra for $\beta$ $\mathrm{La}_{1.85} \mathrm{Ba}_{0.15} \mathrm{Mo}_{2} \mathrm{O}_{8.925}$ and $\beta-\mathrm{La}_{1.7} \mathrm{Bi}_{0.3} \mathrm{Mo}_{2} \mathrm{O}_{9}$ compounds. (4) Comparison of the fraction of nonoccupied volume in $\beta$ $\mathrm{La}_{1.7} \mathrm{Bi}_{0.3} \mathrm{Mo}_{2} \mathrm{O}_{9}$ and in $\beta$ - $\mathrm{La}_{1.85} \mathrm{Ba}_{0.15} \mathrm{Mo}_{2} \mathrm{O}_{8.925}$ above $400{ }^{\circ} \mathrm{C}$ to that determined in $\beta$ - $\mathrm{La}_{2} \mathrm{Mo}_{2} \mathrm{O}_{9}$ at $670{ }^{\circ} \mathrm{C}$. (5) Crystallographic data of $\beta-\mathrm{La}_{1.85} \mathrm{Ba}_{0.15} \mathrm{Mo}_{2} \mathrm{O}_{8.925}$ at $\mathrm{RT}, 100{ }^{\circ} \mathrm{C}, 200{ }^{\circ} \mathrm{C}, 300{ }^{\circ} \mathrm{C}$, $400{ }^{\circ} \mathrm{C}, 500{ }^{\circ} \mathrm{C}, 600{ }^{\circ} \mathrm{C}, 700{ }^{\circ} \mathrm{C}, 800{ }^{\circ} \mathrm{C}$, and $900{ }^{\circ} \mathrm{C}$ in Crystallographic Information File (CIF) format. (6) Crystallographic data of $\beta-\mathrm{La}_{2} \mathrm{Mo}_{2} \mathrm{O}_{9}$ at $670{ }^{\circ} \mathrm{C}$ in Crystallographic Information File (CIF) format.

\section{AUTHOR INFORMATION}

\section{Corresponding Author}

*Tel.: +33 (0)2 438326 48. Fax: +33 (0)2 438335 06. Email: gwenael.corbel@univ-lemans.fr.

\section{Notes}

The authors declare no competing financial interest.

\section{REFERENCES}

(1) Lacorre, P.; Goutenoire, F.; Bohnke, O.; Retoux, R.; Laligant, Y. Nature 2000, 404, 856-858.

(2) Goutenoire, F.; Isnard, O.; Retoux, R.; Lacorre, P. Chem. Mater. 2000, 12, 2575-2580.

(3) Gibson, I. R.; Irvine, J. T. S. J. Mater. Chem. 1996, 6, 895-898.

(4) Tealdi, C.; Chiodelli, G.; Malavasi, L.; Flor, G. J. Mater. Chem. 2004, 14, 3553-3557.
(5) Wang, X. P.; Cheng, Z. J.; Fang, Q. F. Solid State Ionics 2005, 176, $761-765$.

(6) Marrero-Lopez, D.; Perez-Coll, D.; Ruiz-Morales, J. C.; CanalesVazquez, J.; Martin-Sedeno, M. C.; Nunez, P. Electrochim. Acta 2007, 52, 5219-5231.

(7) Selmi, A.; Galven, C.; Corbel, G.; Lacorre, P. Dalton Trans. 2010, 39, 93-102.

(8) Takai, S.; Doi, Y.; Torii, S.; Zhang, J.; Putra, T. Y. S. P.; Miao, P.; Kamiyama, T.; Esaka, T. Solid State Ionics 2013, 238, 36-43.

(9) Wang, X. P.; Fang, Q. F.; Li, Z. S.; Zhang, G. G.; Yi, Z. G. Appl. Phys. Lett. 2002, 81, 3434-3436.

(10) Subramania, A.; Saradha, T.; Muzhumathi, S. J. Power Sources 2007, 167, 319-324.

(11) Marrero-Lopez, D.; Canales-Vazquez, J.; Zhou, W. Z.; Irvine, J. T. S.; Nunez, P. J. Solid State Chem. 2006, 179, 278-288.

(12) Corbel, G.; Durand, P.; Lacorre, P. J. Solid State Chem. 2009, 182, 1009-1016.

(13) Corbel, G.; Chevereau, E.; Kodjikian, S.; Lacorre, P. Inorg. Chem. 2007, 46, 6395-6404.

(14) Marrero-Lopez, D.; Nunez, P.; Abril, M.; Lavin, V.; RodriguezMendoza, U. R.; Rodriguez, V. D. J. Non-Cryst. Solids 2004, 345-46, 377-381.

(15) Georges, S.; Goutenoire, F.; Altorfer, F.; Sheptyakov, D.; Fauth, F.; Suard, E.; Lacorre, P. Solid State Ionics 2003, 161, 231-241.

(16) Voronkova, V. I.; Kharitonova, E. P.; Krasil'nikova, A. E. Crystallogr. Rep. 2010, 55, 276-282.

(17) Basu, S.; Devi, P. S.; Maiti, H. S. J. Electrochem. Soc. 2005, 152, A2143-A2147.

(18) Khadasheva, Z. S.; Venskovskii, N. U.; Safronenko, M. G.; Mosunov, A. V.; Politova, E. D.; Stefanovich, S. Y. Inorg. Mater. 2002, 38, 1168-1171.

(19) Mhadhbi, N.; Corbel, G.; Lacorre, P.; Bulou, A. J. Solid State Chem. 2012, 190, 246-256.

(20) Corbel, G.; Laligant, Y.; Goutenoire, F.; Suard, E.; Lacorre, P. Chem. Mater. 2005, 17, 4678-4684.

(21) Collado, J. A.; Aranda, M. A. G.; Cabeza, A.; Olivera-Pastor, P.; Bruque, S. J. Solid State Chem. 2002, 167, 80-85.

(22) Arulraj, A.; Goutenoire, F.; Tabellout, M.; Bohnke, O.; Lacorre, P. Chem. Mater. 2002, 14, 2492-2498.

(23) Vogel, H. Phys. Z. 1921, 22, 645-646.

(24) Tammann, G.; Hesse, W. Z. Anorg. Allg. Chem. 1926, 156, $245-$ 257.

(25) Fulcher, G. S. J. Am. Ceram. Soc. 1925, 8, 339-355.

(26) Corbel, G.; Suard, E.; Lacorre, P. Chem. Mater. 2011, 23, $1288-$ 1298.

(27) Lacorre, P.; Selmi, A.; Corbel, G.; Boulard, B. Inorg. Chem. 2006, 45, 627-635.

(28) Cohen, M. H.; Turnbull, D. J. Chem. Phys. 1959, 31, 11641169.

(29) Shannon, R. D. Acta Crystallogr., Sect. A: Cryst. Phys., Diffr., Theor.: Gen. Crystallogr. 1976, 32, 751-767.

(30) Dienes, G. J. J. Appl. Phys. 1953, 24, 779-782.

(31) Macedo, P. B.; Litovitz, T. A. J. Chem. Phys. 1965, 42, 245-256.

(32) Rodriguez Carvajal, J. Physica B 1993, 192, 55-69.

(33) Berar, J. F.; Baldinozzi, G. J. Appl. Crystallogr. 1993, 26, 128129.

(34) Fender, B. E. F. Chemical Applications of Thermal Neutron Scattering; Willis, B. T. M., Ed.; Oxford University Press: London, 1974.

(35) Aldebert, P.; Dianoux, A. J.; Traverse, J. P. J. Phys. (Paris) 1979, 40, 1005-1012.

(36) Johnson, P. A. V.; Wright, A. C.; Sinclair, R. N. J. Non-Cryst. Solids 1983, 58, 109-130.

(37) Bergerhoff, G.; Berndt, M.; Brandenburg, K. J. Res. Natl. Inst. Stand. Technol. 1996, 101, 221-225.

(38) Hamilton, W. C. Acta Crystallogr. 1959, 12, 609-610.

(39) Brown, I. D.; Dabkowski, A.; McCleary, A. Acta Crystallogr., Sect. B: Struct. Sci. 1997, 53, 750-761. 
(40) Andersson, S.; Åström, A. NBS Special Publication 364, Solid State Chemistry. In Proceedings of the 5th Material Research Symposium, 1972; p 3.

(41) Emery, J.; Massiot, D.; Lacorre, P.; Laligant, Y.; Conder, K. Magn. Reson. Chem. 2005, 43, 366-371.

(42) CRC Handbook of Chemistry and Physics 2008-2009: A ReadyReference Book of Chemical and Physical Data; 89th Edition; Lide, D. R., Ed.; CRC Press: Boca Raton, FL, 2008.

(43) Kröger, F. A.; Vink, H. J. Solid State Phys. 1956, 3, 307-435.

(44) Souquet, J.-L.; Nascimento, M. L. F.; Rodrigues, A. C. M. J. Chem. Phys. 2010, 132, 034704.

(45) Zhang, G. B.; Smyth, D. M. Solid State Ionics 1995, 82, 161172.

(46) Zacate, M. O.; Minervini, L.; Bradfield, D. J.; Grimes, R. W.; Sickafus, K. E. Solid State Ionics 2000, 128, 243-254.

(47) Bogicevic, A.; Wolverton, C.; Crosbie, G. M.; Stechel, E. B. Phys. Rev. B 2001, 64, 014106.

(48) Li, P.; Chen, I. W.; Penner-Hahn, J. E. Phys. Rev. B 1993, 48, 10074-10081.

(49) Maekawa, H.; Kawata, K.; Xiong, Y. P.; Sakai, N.; Yokokawa, H. Solid State Ionics 2009, 180, 314-319.

(50) Badwal, S. P. S.; Ciacchi, F. T.; Milosevic, D. Solid State Ionics 2000, 136-137, 91-99. 